\title{
Ichthyotoxic Cochlodinium polykrikoides red tides offshore in the South Sea, Korea in 2014: I. Temporal variations in three-dimensional distributions of red-tide organisms and environmental factors
}

\author{
Hae Jin Jeong, ${ }^{1,2, *}$, An Suk Lim ${ }^{1,3}$, Kitack Lee ${ }^{4}$, Moo Joon Lee ${ }^{5}$, Kyeong Ah Seong ${ }^{6}$, Nam \\ Seon Kang ${ }^{1}$, Se Hyeon Jang ${ }^{1}$, Kyung Ha Lee ${ }^{1}$, Sung Yeon Lee ${ }^{1}$, Mi Ok Kim ${ }^{4}$, Ji Hye Kim${ }^{1}$, Ji \\ Eun Kwon ${ }^{1}$, Hee Chang Kang ${ }^{1}$, Jae Seong Kim ${ }^{7}$, Wonho Yih ${ }^{6}$, Kyoungsoon Shin ${ }^{8}$, Poong \\ Kook Jang ${ }^{8}$, Joo-Hyung Ryu ${ }^{8}$, Sung Young Kim ${ }^{9}$, Jae Yeon Park ${ }^{2}$ and Kwang Young Kim ${ }^{10}$ \\ ${ }^{1}$ School of Earth and Environmental Sciences, College of Natural Sciences, Seoul National University, Seoul 08826, Korea \\ ${ }^{2}$ Advanced Institutes of Convergence Technology, Suwon 16229, Korea \\ ${ }^{3}$ Brain Korea 21 Plus, School of Earth and Environmental Sciences, College of Natural Sciences, Seoul National University, \\ Seoul 08826, Korea \\ ${ }^{4}$ School of Environmental Science and Engineering, Pohang University of Science and Technology, Pohang 37673, Korea \\ ${ }^{5}$ Department of Marine Biotechnology, Anyang University, Incheon 23038, Korea \\ ${ }^{6}$ Department of Marine Biotechnology, Kunsan National University, Kunsan 54150, Korea \\ ${ }^{7}$ Water and Eco-Bio Corporation, Kunsan National University, Kunsan 54150, Korea \\ ${ }^{8}$ Korea Institute of Ocean Science \& Technology, Ansan 15627, Korea \\ ${ }^{9}$ Department of Mechanical Engineering, Korea Advanced Institute of Science and Technology, Daejeon 34141, Korea \\ ${ }^{10}$ Department of Oceanography, Chonnam National University, Gwangju 61186, Korea
}

The ichthyotoxic Cochlodinium polykrikoides red tides have caused great economic losses in the aquaculture industry in the waters of Korea and other countries. Predicting outbreak of C. polykrikoides red tides 1-2 weeks in advance is a critical step in minimizing losses. In the South Sea of Korea, large C. polykrikoides red tide patches have often been recorded offshore and transported to nearshore waters. To explore the processes of offshore C. polykrikoides red tides, temporal variations in 3-dimensional (3-D) distributions of red tide organisms and environmental parameters were investigated by analyzing 4,432 water samples collected from 2-5 depths of 60 stations in the South Sea, Korea 16 times from May to Nov, 2014. In the study area, the vegetative cells of $C$. polykrikoides were found as early as May 7, but C. polykrikoides red tide patches were observed from Aug 21 until Oct 9. Cochlodinium red tides occurred in both inner and outer stations. Prior to the occurrence of large C. polykrikoides red tides, the phototrophic dinoflagellates Prorocentrum donghaiense (Jun 12 to Jul 11), Ceratium furca (Jul 11 to Aug 21), and Alexandrium fraterculus (Aug 21) formed red tides in sequence, and diatom red tides formed 2-3 times without a certain distinct pattern. The temperature for the optimal growth of these four red tide dinoflagellates is known to be similar. Thus, the sequence of the maximum growth rates of $P$. donghaiense $>$ C. furca $>$ A. fraterculus $>$ C. polykrikoides may be partially responsible for this sequence of red tides in the inner stations following high nutrients input in the surface waters because of heavy rains. Furthermore, Cochlodinium red tides formed and persisted at the outer stations when $\mathrm{NO}_{3}$ concentrations of the surface waters were $<2 \mu \mathrm{M}$ and thermocline depths were $>20$ m with the retreat of deep cold waters, and the abundance of the competing red-tide species was relatively low. The sequence of the maximum swimming speeds and thus potential reachable depths of C. polykrikoides $>$ A. fraterculus

(P) $\$$ This is an Open Access article distributed under the terms of the Creative Commons Attribution Non-Commercial License (http://creativecommons.org/licenses/by-nc/3.0/) which permits unrestricted non-commercial use, distribution, and reproduction in any medium, provided the original work is properly cited.
Received March 15, 2017, Accepted May 30, 2017

*Corresponding Author

E-mail: hjjeong@snu.ac.kr

Tel: +82-2-880-6746, Fax: +82-2-874-9695 
$>$ C. furca $>$ P. donghaiense may be responsible for the large C. polykrikoides red tides after the small blooms of the other dinoflagellates. Thus, C. polykrikoides is likely to outgrow over the competitors at the outer stations by descending to depths $>20 \mathrm{~m}$ and taking nutrients up from deep cold waters. Thus, to predict the process of Cochlodinium red tides in the study area, temporal variations in 3-D distributions of red tide organisms and environmental parameters showing major nutrient sources, formation and depth of thermoclines, intrusion and retreat of deep cold waters, and the abundance of competing red tide species should be well understood.

Key Words: diatom; dinoflagellate; harmful algal bloom; mixotroph; protist

\section{INTRODUCTION}

Red tides, the discoloration of the sea surface because of plankton blooms, occur in nearshore and offshore waters worldwide (Holmes et al. 1967, Eppley and Harrison 1975, Franks and Anderson 1992, Anderson 1995, Franks 1997a, Horner et al. 1997, Sordo et al. 2001, Anderson et al. 2002, Alonso-Rodríguez and Ochoa 2004, Imai et al. 2006, Seong et al. 2006, Jeong et al. 2013). Red tides are often causing large-scale fish and shellfish mortalities and great economic losses to the aquaculture and tourist industries (Smayda 1990, Glibert et al. 2005, Anderson et al. 2012, Fu et al. 2012, Park et al. 2013b). Therefore, many countries spend considerable amounts on minimizing the economic losses caused by red tides. Understanding and predicting the outbreak, persistence, and decline of red tides, and establishing early warning systems, are critical steps in minimizing the economic losses. Various physical, chemical, and biological parameters have been known to affect red tide processes of one species (Franks 1997a, 1997b, Smayda 2010, Lee et al. 2014b, 2016, Lim et al. 2014, 2015, Menden-Deuer and Montalbano 2015, Jeong et al. 2016). Furthermore, the outbreak mechanisms differ between species (e.g., Jeong et al. 2015). Therefore, the red tide processes should be understood at species level.

The ichthyotoxic dinoflagellate Cochlodinium polykrikoides is a mixotrophic dinoflagellate that forms red tides in the waters of many countries (Jeong et al. 2004, 2008, Azanza et al. 2008, Gobler et al. 2008, Mulholland et al. 2009, Kudela and Gobler 2012, Mohammad-Noor et al. 2014, Al-Hashmi et al. 2015, Lim et al. 2015). It has caused large-scale mortality of finfish in both cages and natural environments (Whyte et al. 2001, Fukuyo et al. 2002, Yan et al. 2002, Gárate-Lizárraga et al. 2004, VargasMontero et al. 2006, Anton et al. 2008, Azanza et al. 2008, Hamzehei et al. 2013, Park et al. 2013b, Lim et al. 2017), and is responsible for USD \$1-60 million losses to Korea's aquaculture industry every year (Park et al. 2013b). The
Korean federal and local governments and the aquaculture industry have spent over USD \$20 million every year to minimize this loss. In Korea, C. polykrikoides red tides usually first appear in the South Sea and then move to the West Sea (Yellow Sea) and / or East Sea (Sea of Japan) (Lee et al. 2013). These red tides have sometimes been transported to the waters of western Japan (Onitsuka et al. 2010). Thus, the effective and accurate prediction of the outbreak, persistence, and decline of C. polykrikoides red tides in the South Sea of Korea, where aquaculture cages are very concentrated and great economic losses owing to C. polykrikoides red tides occur every year, is an important task for scientists. Understanding the conditions under which C. polykrikoides red tides occur is the first step in predicting a red tide outbreak. The establishment of an early warning system for red tide outbreaks can allow aquaculture farmers to harvest fish earlier, move their cages to relatively safe areas, or be prepared to use effective removal materials such as clay, $\mathrm{NaOCl}$, or suitable organisms (Jeong et al. 2002, 2008, Park et al. 2013b, Lee et al. 2014a).

C. polykrikoides red tides occur in waters with a wide range of temperature, salinity, and nutrient concentrations (Gobler et al. 2008, Kudela et al. 2008, Mulholland et al. 2009, Fatemi et al. 2012, Kudela and Gobler 2012, Al-Azri et al. 2013), and C. polykrikoides cells are present in waters with even wider ranges (Yamatogi et al. 2006, Gobler et al. 2008, Tomas and Smayda 2008). The diversity in C. polykrikoides ribotypes, as well as the location and mechanisms of outbreaks, may be responsible for the wide range of these critical environmental parameters (Gobler et al. 2008, Iwataki et al. 2008, Kudela et al. 2008, Lee et al. 2009, 2013, Mulholland et al. 2009, Morse et al. 2011, 2013, Fatemi et al. 2012, Kudela and Gobler 2012, Al-Azri et al. 2013, 2015, Park et al. 2013a, 2014). Three $C$. polykrikoides ribotypes (East Asian type, United States / Malaysian type, and Philippine type) have been reported 
(Iwataki et al. 2008, Park et al. 2014). The three types may differ in their ecophysiology, and thus, growth factors and outbreak mechanisms may differ between types. The environment of the South Sea of Korea, where C. polykrikoides red tides most frequently occur, is very different from that of the east coast of the United States. In the South Sea of Korea, C. polykrikoides red tides have often been found in offshore, as well as nearshore waters (Han et al. 2008, Lee et al. 2013), whereas in the east coast of the United States, they have been found in estuaries or bays (Nuzzi 2004, Tomas and Smayda 2008, Morse et al. 2013). Thus, in order to understand C. polykrikoides red tides, the processes and favorable conditions for C. polykrikoides optimal growth in different environments should be well understood and data from several countries should be combined.

There are two main questions on the process of $C$. polykrikoides red tides in the South Sea of Korea: 1) what are critical physical, chemical, and biological parameters affecting the outbreak, persistence, and decline of C. polykrikoides?; 2) how can C. polykrikoides form huge red tide patches offshore where nutrient concentrations in the surface waters are usually very low? There have been theoretical explanations on these questions, but they have not been well proved at sea yet; C. polykrikoides is relatively slow growing red tide organisms (maximum autotrophic growth rates of most strains $=\sim 0.4 \mathrm{~d}^{-1}$ ) (Kim et al. 2001, 2004, Jeong et al. 2010, 2015). Thus, C. polykrikoides may not have a chance to outgrow over red tide diatoms, flagellates, and most dinoflagellates when the conditions favorable for photosynthesis are given. However, C. polykrikoides is one of the fastest-swimming phototrophic dinoflagellates (Jeong et al. 1999, 2015, Smayda 2010); it can swim at a maximum speed of ca. $1.4 \mathrm{~mm} \mathrm{~s}^{-1}$ and, theoretically, can reach a $50 \mathrm{~m}$ depth if it descends for $10 \mathrm{~h}$ (Jeong et al. 2015). Thus, C. polykrikoides may outgrow over competing red tide species when nutrient concentrations in the surface waters are low and those in the deep water are high and also the thermocline which splits well-lit but low-nutrient surface waters from highly eutrophic deep waters is positioned deep for C. polykrikoides to reach highly eutrophic deep waters, but competitors do not to reach. Such conditions may be given offshore in the high solar insolation period. Thus, relative growth rates and vertical migration abilities of red tide species, thermocline depth, stratification, nutrient supply sources, and competition among red tide species are critical factors affecting dynamics of C. polykrikoides red tides. Furthermore, to explore these parameters or factors, 3-dimentional (3-D) distributions of red-tide species and environmental factors before, during, after the outbreak of C. polykrikoides red tide should be investigated. However, these 3-D distributions and their temporal variations have not been explored in the South Sea of Korea yet.

In this study, in order to investigate temporal variations in 3-D distributions of red tide organisms and environmental parameters, water samples were collected from 60 stations (mostly offshore) in the South Sea of Korea, from May to Nov 2014. The abundances of C. polykrikoides and other phytoplankton species, as well as temperature, salinity, and nutrient concentrations were analyzed. The results of the analyses provided an understanding of the formation and depth of thermoclines, the intrusion and retreat of deep cold waters, and the distribution of eutrophic waters at the surface and deep waters. Simultaneously, the temporal and spatial distributions of heterotrophic protistan and metazoan grazers and their grazing impacts on red-tide organisms were investigated (Lim et al. companion paper, Lee et al. companion paper). The results of the present study provide a basis for understanding the processes of C. polykrikoides red tides occurring in the waters of Korea and other countries. They also provide an understanding of the critical physical, chemical, and biological parameters affecting C. polykrikoides red tides, for establishing C. polykrikoides red tide outbreak, persistence, and decline prediction models, and for developing effective systems of minimizing economic losses owing to C. polykrikoides red tides.

\section{MATERIALS AND METHODS}

\section{Sampling stations}

Sixty stations were located in nearshore and offshore waters in the South Sea of Korea (Fig. 1), with most stations located offshore. The study area (approximately 140 $\mathrm{km} \times 40 \mathrm{~km}$ ) consisted of three locations: a western area between Goheung and Yeosu, a middle area between Yeosu and Namhae, and an eastern area between Namhae and Tongyoung. The water depth for all sampling stations ranged between 4-53 $\mathrm{m}$. The stations in the western area were shallower than those in the eastern area at the same latitude (Fig. 1). St 501 in the middle area was located approximately $20 \mathrm{~km}$ south of the Seumjin River (SJ River), while St 201 in the western area was located approximately $5 \mathrm{~km}$ southeast of the relatively small Haechang Bay (HC Bay) and St 301 approximately $10 \mathrm{~km}$ south of the large Yeoja Bay (YJ Bay). To compare average or maxi- 

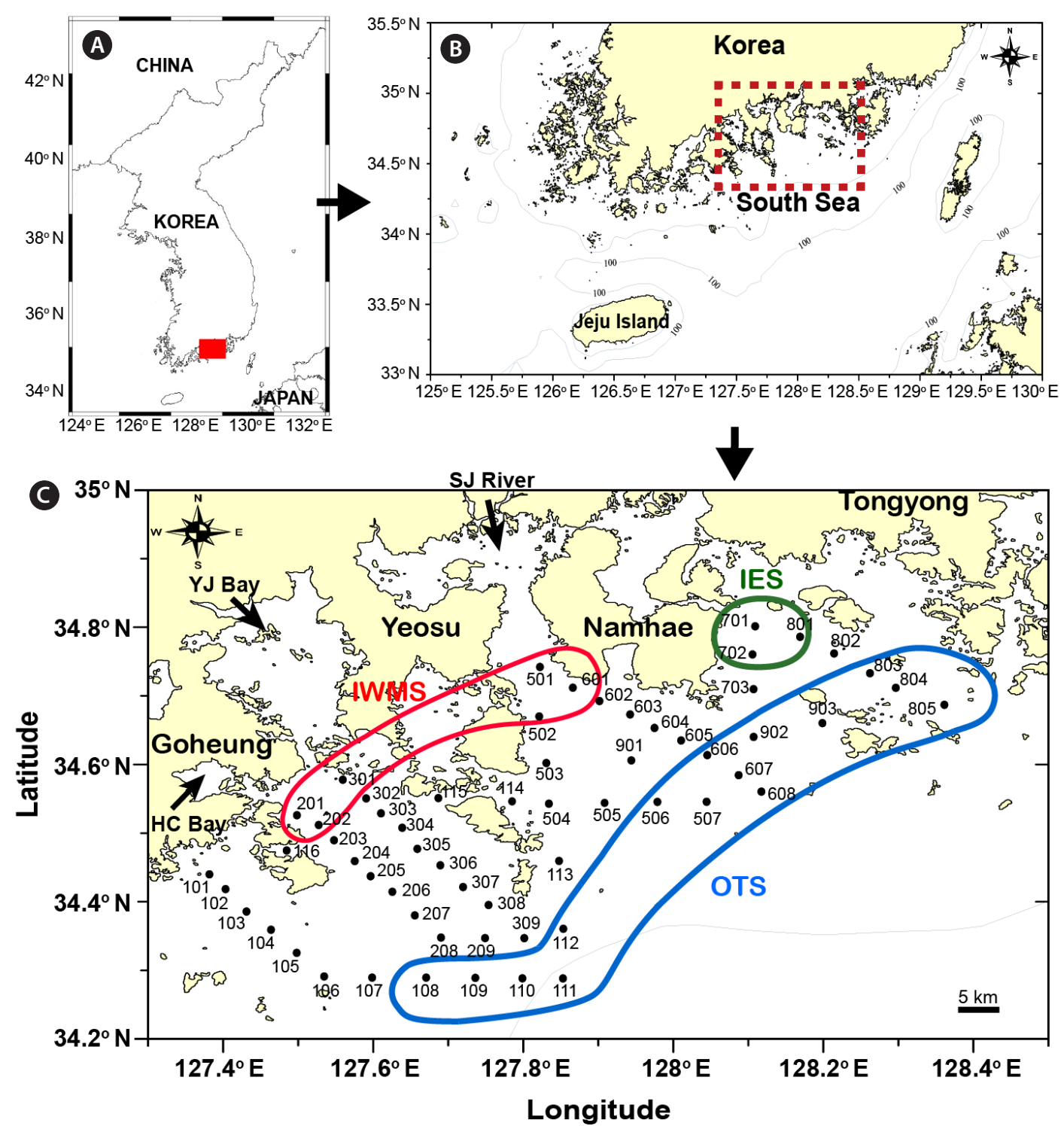

D

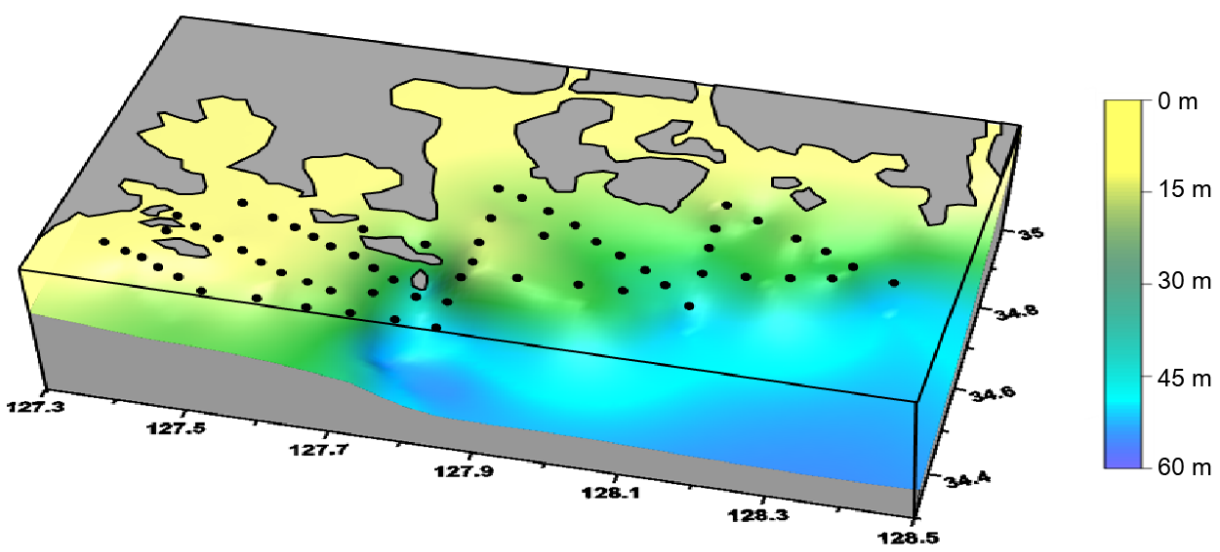

Fig. 1. Sampling areas and stations in the South Sea of Korea (A-C) and bottom topography (D). The red circle indicates the selected inner stations of the western and middle areas (IWMS); the green circle, the selected inner stations of the eastern area (IES); and the blue circle, the selected outer stations (OTS) (see text for details). The arrow in Goheung in (C) indicates Haechang Bay (HC Bay), the arrow between Goheung and Yeosu indicates Yeoja Bay (YJ Bay), and the arrow between Yeosu and Namhae indicates Seomjin River (SJ River). 
mum values of critical environmental parameters, such as temperature, salinity, nutrient concentrations, and red tide species, representative stations in each area were selected based on the distribution of salinity following heavy rains (Fig. 1). Following heavy rains, freshwater input from SJ River, HC Bay, and YJ Bay largely reduced the salinity at the inner stations of the western and middle areas (IWMS; St 201, 202, 301, 501, 502, and 601), but less at the inner stations of the eastern area (IES; St 701, 702, and 801). In addition, St 108-112, 506-507, 606-608, 803805 , and 902-903 were selected as the outer stations (OTS) because the salinity at these stations was not markedly affected by freshwater input. The depth range was 8-20 m in the IWMS, 16-25 $\mathrm{m}$ in the IES, and 27-54 $\mathrm{m}$ in the OTS. The tidal ranges in the coasts of Goheung and Tongyoung were approximately 3-4 and 2-3 m, respectively.

\section{Sampling and analyses of meteorological, physi- cal, chemical, and biological properties}

Sixteen sampling cruises were carried out at 1-2 weeks intervals between May 7 and Nov 11, 2014 (Table 1). A two-day sampling was carried out by two ships. On the first day, water samples were collected from one ship at stations 101-114, while the other ship collected samples at stations 201-309. On the second day, one ship collected water samples at stations 501-507 and 601-608, while the other ship at stations 701-703, 801-805, and 901-904. The sampling time at the first station in each sampling day was between 07:30-08:00 $\mathrm{h}$ and at the last station was be- tween 14:00-15:00 h.

Water temperature (WT) and salinity in the water column were measured using two CTDs (YSI6600; YSI Inc., Yellow Springs, OH, USA \& Ocean seven; Idronaut S.r.l., Milan, Italy). The data obtained from the CTDs were calibrated in each cruise. Additionally, the temperature, salinity, $\mathrm{pH}$, and dissolved oxygen for each sampling depth were measured using an YSI Professional Plus instrument (YSI Inc.). The water samples for nutrient concentration analysis were gently filtered through GF/F filters and stored at $-20^{\circ} \mathrm{C}$ until the concentrations of nitrate plus nitrite $\left(\mathrm{NO}_{3}+\mathrm{NO}_{2}\right.$, hereafter $\left.\mathrm{NO}_{3}\right)$ and phosphate $\left(\mathrm{PO}_{4}\right)$ were measured using a nutrient auto-analyzer system (Quattro; Seal Analytical Gmbh, Norderstedt, Germany). The chlorophyll $a$ concentration was measured as described in Eaton et al. (1995).

Water samples at each station were collected using water samplers, from 2-5 depths depending on the depth of each station. Samples for phytoplankton counting were collected into $500-\mathrm{mL}$ polyethylene bottles and preserved with acidic Lugol's solution. To determine the abundance of each phytoplankton species, the preserved samples were concentrated by $1 / 5-1 / 10$ using the settling and siphoning method (Welch 1948). After thorough mixing, all or a minimum of 100 cells of each phytoplankton species in one to ten 1-mL Sedgwick-Rafter counting chambers were counted under a light microscope.

The air temperature (AT) and precipitation data during this study were obtained from the Korea Meteorological Administration (KMA, http://web.kma.go/kr). In addi-

Table 1. Sampling dates and range of water temperature $(\mathrm{T})$, salinity $(\mathrm{S})$, and concentration of nitrate $\left(\mathrm{NO}_{3}\right)$ and phosphate $\left(\mathrm{PO}_{4}\right)$, in the surface and bottom waters at all stations

\begin{tabular}{|c|c|c|c|c|c|c|c|c|}
\hline \multirow{2}{*}{$\begin{array}{c}\text { Sampling dates } \\
\text { of each cruise (2014) }\end{array}$} & \multicolumn{2}{|c|}{$\mathrm{T}\left({ }^{\mathrm{o}} \mathrm{C}\right)$} & \multicolumn{2}{|c|}{$S$} & \multicolumn{2}{|c|}{$\mathrm{NO}_{3}(\mu \mathrm{M})$} & \multicolumn{2}{|c|}{$\mathrm{PO}_{4}(\mu \mathrm{M})$} \\
\hline & Surface & Bottom & Surface & Bottom & Surface & Bottom & Surface & Bottom \\
\hline May 7-8 & $14.6-16.9$ & $13.6-16.4$ & $33.3-34.3$ & $33.9-34.3$ & $0.1-1.8$ & $0.2-2.5$ & $0.0-0.8$ & $0.1-0.4$ \\
\hline May 21-22 & $15.1-19.1$ & $14.6-18.9$ & $33.4-34.2$ & $33.7-34.2$ & $0.0-1.8$ & $0.1-2.9$ & $0.0-0.3$ & $0.0-0.7$ \\
\hline Jun 5-6 & $16.5-19.9$ & $15.2-20.2$ & $32.5-34.3$ & $33.4-34.3$ & $0.0-3.3$ & $0.0-3.5$ & $0.0-0.3$ & $0.0-0.4$ \\
\hline Jun $12-13$ & $18.2-21.6$ & $15.3-20.8$ & $33.3-34.1$ & $33.4-34.4$ & $0.0-1.0$ & $0.1-7.6$ & $0.0-0.2$ & $0.0-0.5$ \\
\hline Jun 23-24 & $16.7-22.4$ & $15.8-21.9$ & $33.5-34.2$ & $33.4-34.3$ & $0.1-4.1$ & $0.1-5.0$ & $0.0-0.5$ & $0.0-0.6$ \\
\hline Jul 1-2 & $20.6-23.6$ & $15.3-22.8$ & $32.7-33.8$ & $32.8-34.0$ & $0.1-1.1$ & $0.2-5.1$ & $0.0-0.4$ & $0.0-0.6$ \\
\hline Jul 11-12 & $21.7-23.6$ & $16.6-23.2$ & $32.8-33.8$ & $33.2-34.1$ & $0.1-1.7$ & $0.0-1.7$ & $0.0-0.4$ & $0.0-0.5$ \\
\hline Jul 22-23 & $22.5-25.9$ & $14.9-24.9$ & $31.5-33.7$ & $32.3-34.2$ & $0.1-1.5$ & $0.1-9.6$ & $0.0-0.2$ & $0.0-0.6$ \\
\hline Aug 6-7 & $22.8-26.6$ & $14.3-25.2$ & $25.9-32.9$ & $31.5-35.8$ & $0.2-45.1$ & $0.5-16.2$ & $0.1-0.9$ & $0.1-0.9$ \\
\hline Aug 13-14 & $22.7-25.6$ & $14.6-25.0$ & $30.8-32.9$ & $31.2-34.5$ & $0.0-6.8$ & $0.2-9.2$ & $0.0-0.4$ & $0.1-0.7$ \\
\hline Aug 21-22 & $23.5-25.3$ & $14.4-25.0$ & $23.5-32.2$ & $30.9-34.0$ & $0.1-30.1$ & $0.2-11.2$ & $0.0-1.7$ & $0.1-1.2$ \\
\hline Sep 1-2 & $22.7-24.3$ & $18.7-24.2$ & $28.7-32.6$ & $30.9-33.4$ & $0.1-7.7$ & $0.2-11.2$ & $0.0-0.5$ & $0.0-0.7$ \\
\hline Sep 15-16 & $22.8-25.4$ & $15.5-24.0$ & $31.4-33.4$ & $31.4-34.5$ & $0.1-1.5$ & $0.2-3.6$ & $0.0-1.5$ & $0.1-0.5$ \\
\hline Sep 28-29 & $23.0-25.2$ & $15.1-23.5$ & $31.1-33.1$ & $31.6-34.4$ & $0.2-6.1$ & $0.3-15.3$ & $0.0-0.4$ & $0.0-1.3$ \\
\hline Oct 9-10 & $21.9-22.8$ & $21.7-22.8$ & $31.7-33.2$ & $31.7-33.4$ & $0.2-6.7$ & $0.2-7.6$ & $0.0-0.6$ & $0.1-0.7$ \\
\hline Nov $10-11$ & $17.2-19.3$ & $15.9-19.3$ & $32.7-33.9$ & $32.7-35.0$ & $2.0-10.0$ & $1.9-9.8$ & $0.1-0.7$ & $0.2-1.1$ \\
\hline
\end{tabular}



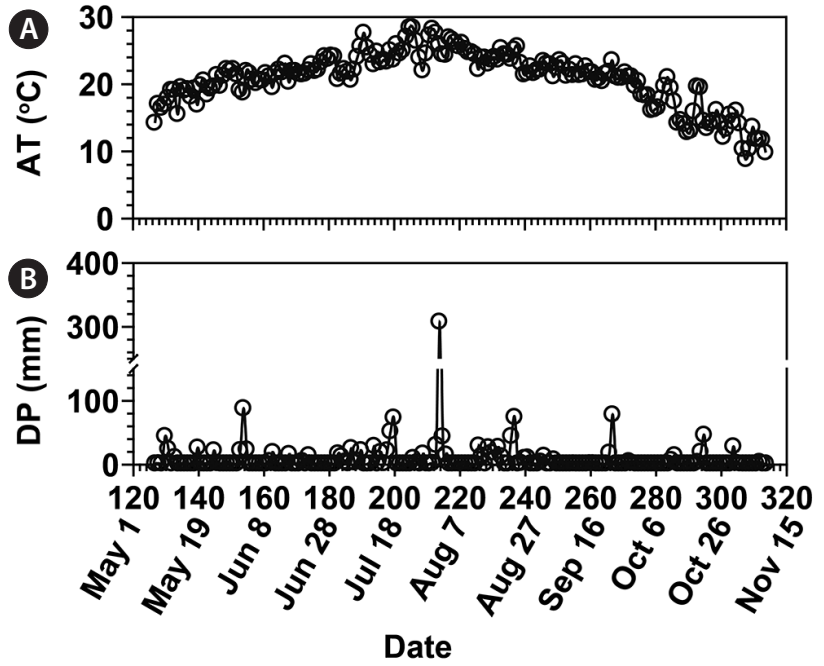

Fig. 2. Meteorological properties measured in Goheung from May 7 to Nov 11,2014 . (A) Air temperature (AT, $\left.{ }^{\circ} \mathrm{C}\right)$. (B) Daily precipitation (DP, mm).

tion, the data on tidal height in the coasts of Goheung and Tongyoung were obtained from the Korea Hydrographic and Oceanographic Agency (KHOA, http://eng.khoa. go.kr).

\section{Data process}

The 3-D distributions of temperature, salinity, the concentrations of $\mathrm{NO}_{3}$ and $\mathrm{PO}_{4}$, and the abundance of total diatoms and red-tide dinoflagellates were compiled using the Surfer 9 software (Golden Software, LLC, Golden, CO, USA). In addition, the average temperature, thermocline depth, salinity, $\mathrm{NO}_{3}$, or $\mathrm{PO}_{4}$ in the surface or bottom waters at each cruise was calculated by averaging all values from all stations of each of the IWMS, IES, and OTS. However, the maximum abundance of total diatoms and the red-tide dinoflagellates Prorocentrum donghaiense, Ceratium furca, Alexandrium fraterculus, and C. polykrikoides at each cruise were obtained by selecting the highest value among the values measured at all stations of each of the IWMS, IES, and OTS because red tide patches often move from the station where the patches formed to adjacent stations. The thermocline depth at each station of the South Sea of Korea was determined according to Yoon and Choi (2012); the existence of a thermocline was determined as the maximum WT gradient (maximum $\Delta \mathrm{T}$ ) of $\geq 0.5^{\circ} \mathrm{C} \mathrm{m}^{-1}$ and temperature difference $(\Delta \mathrm{T})$ in surface and bottom layers $<|0.2|^{\circ} \mathrm{C}$. When a thermocline existed at the station, the depth where $\Delta \mathrm{T}$ is $\geq 0.5^{\circ} \mathrm{C} \mathrm{m}^{-1}$ was determined as the thermocline depth of the station.

\section{RESULTS}

\section{Meteorological data}

During the study period, the AT in Goheung ranged between 8.7 and $28.3^{\circ} \mathrm{C}$ (Fig. 2A); the highest AT was observed on Jul 23, while the lowest AT was observed on Nov 3 . Daily precipitation (DP) ranged from 0 to $307 \mathrm{~mm}$ (Fig. 2B); DP over $50 \mathrm{~mm}$ was observed on Jun 2, Jul 17, Aug 1, Aug 24, and Sep 23.

\section{Temporal variations in 3-D distributions of red tide species and environmental factors}

In the 3-D distribution of WT during the study period, the WTs at the shallower inner stations of the western area were higher than those at the deeper areas (Fig. 3). The WT increased from May 7 to Sep 28 and strong thermoclines formed from Aug 6 to Sep 28 (Fig. 3). From Jul 22 to Aug 21, the highest surface WTs among all stations were $25.3-26.6^{\circ} \mathrm{C}$, while the lowest bottom WTs were 14.3$14.9^{\circ} \mathrm{C}$ (Table 1). During this period, intrusion of deep cold waters occurred. However, on Sep 1, the highest surface WT was $24.3^{\circ} \mathrm{C}$, while the lowest bottom WT was $18.7^{\circ} \mathrm{C}$, which indicated retreat of the intruded deep cold waters (Table 1, Fig. 3). However, the deep cold-water intrusions occurred again on Sep 15 and 28. The thermocline at all stations almost disappeared on Oct 9 (Fig. 3).

In general, the salinity of the surface waters in the inner stations of the western and middle areas were lower than those in the eastern area and outer stations (Fig. 3). The salinity in the surface waters was relatively high from May 7 to Jul 11, but became lower from Jul 22 to Oct 9 (Fig. 3). The lowest and second lowest salinity in the surface waters (23.5 and 25.9) during the study period was observed on Aug 21 and 6, respectively (Table 1, Fig. 3). However, the highest and second highest salinity in the bottom waters (35.8 and 34.5) was observed on Aug 6 and 13, which indicated the intrusion of high salinity, deep cold waters (Fig. 3). Furthermore, an intrusion of these high salinity deep cold waters occurred again between Sep 15 and 28. The salinity in the surface and deep waters increased from Oct 9 to Nov 10.

The nitrate $\left(\mathrm{NO}_{3}\right)$ concentration in the surface waters from May 7 to Jul 22 were relatively low $(<2 \mu \mathrm{M})$, with the exception of Jun 5 and 23 (Table 1, Fig. 3). The highest $\mathrm{NO}_{3}$ concentration on Jun 5 and 23 was 3.3-4.1 $\mu$ M. However, on Aug 6, the $\mathrm{NO}_{3}$ concentration largely increased in the surface waters of the inner stations (highest $\mathrm{NO}_{3}$ concentration $=45.1 \mu \mathrm{M}$ ) and in the deep cold waters of 


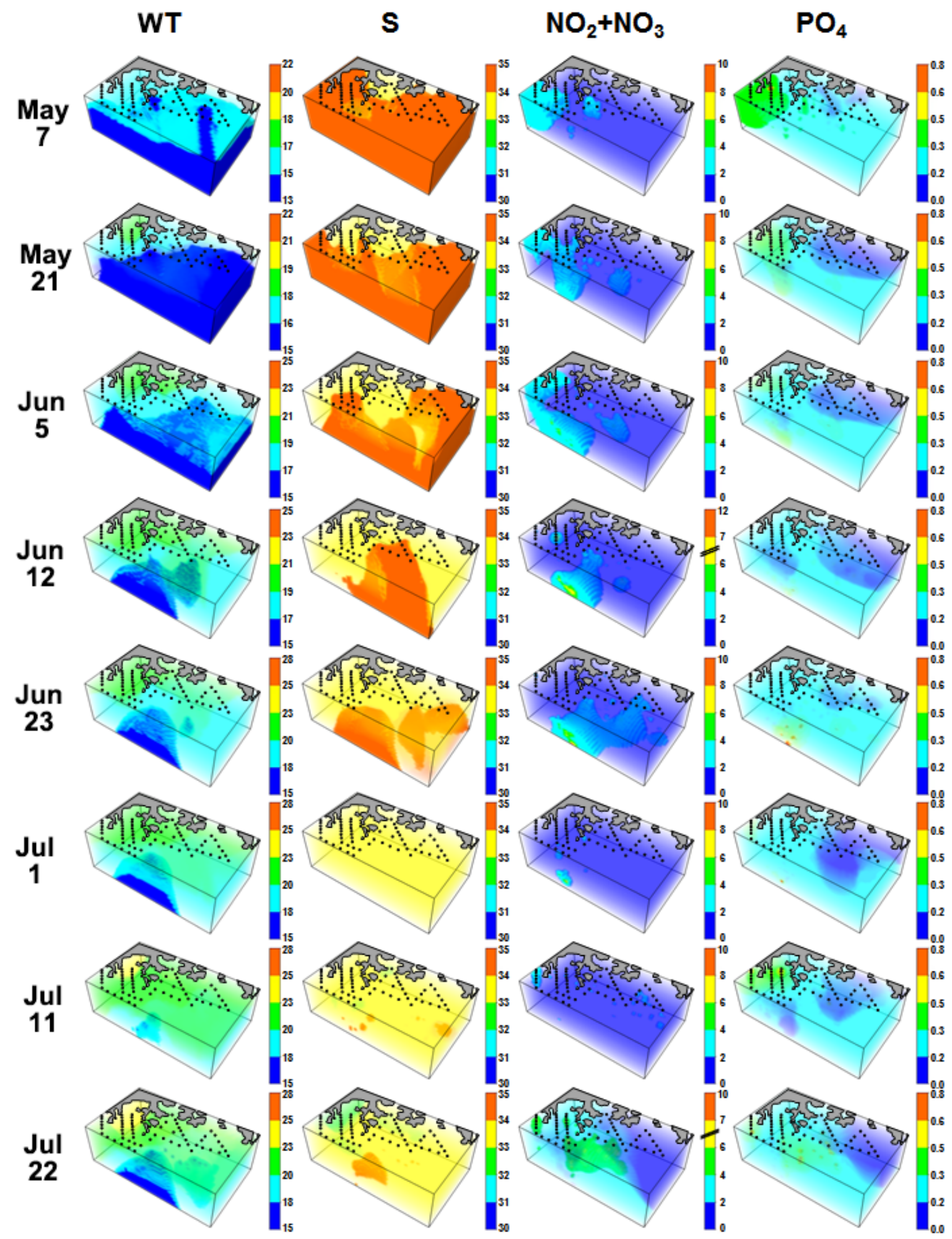

Fig. 3. Three-dimensional distributions of water temperature (WT), salinity (S), nitrate $\left(\mathrm{NO}_{3}\right)$, and phosphate $\left(\mathrm{PO}_{4}\right)$ in the study area at each cruise from May 7 to Nov 11, 2014. 


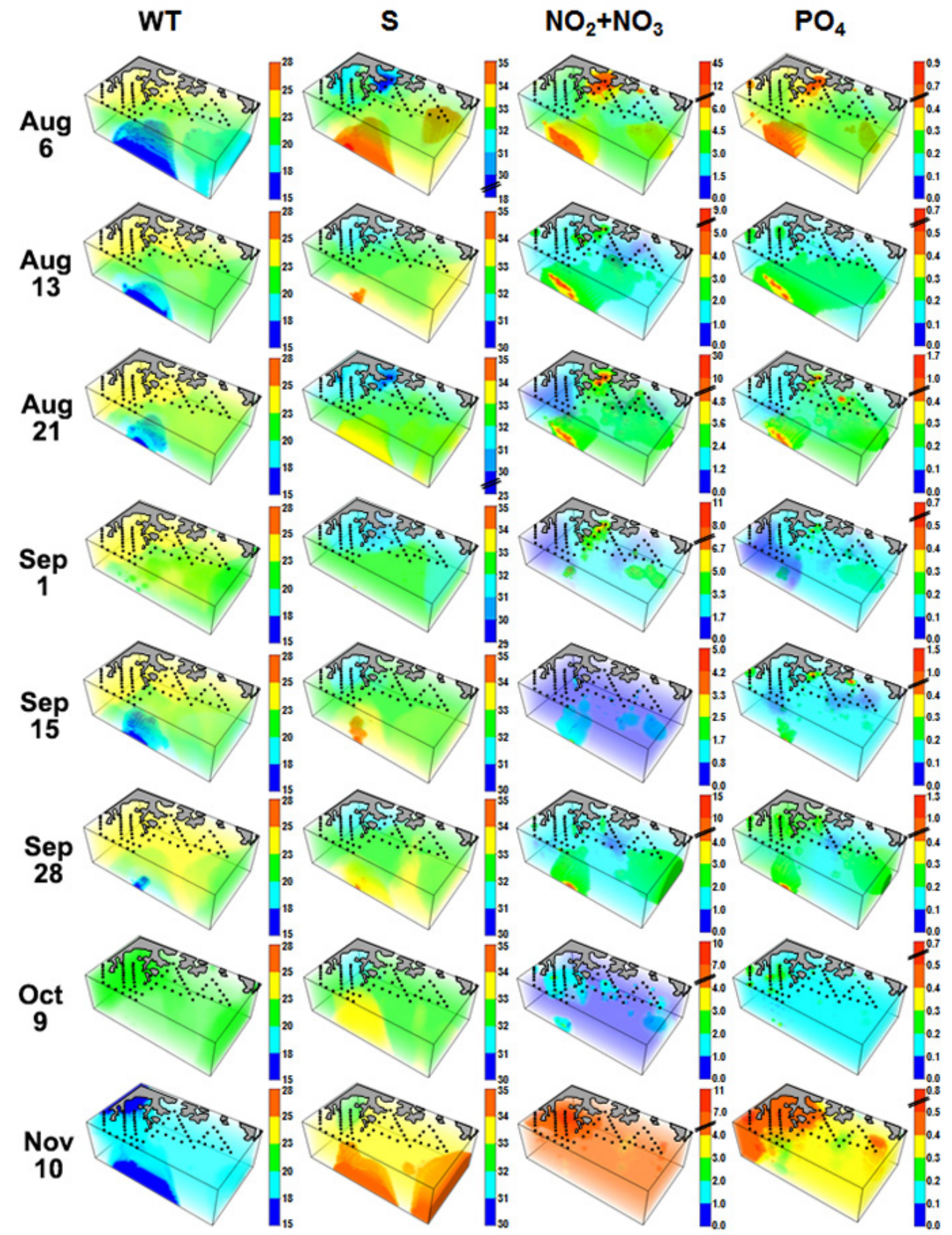

Fig. 3. Continued. 
the outer stations (highest $\mathrm{NO}_{3}$ concentration $=16.2 \mu \mathrm{M}$ ), which indicated two different $\mathrm{NO}_{3}$ sources. Furthermore, the distribution of $\mathrm{NO}_{3}$ concentration on Aug 13 and 21 was similar to that on Aug 6, but the magnitude of the concentration on Aug 13 and 21 was smaller than that on Aug 6 (Table 1, Fig. 3). In addition, the phosphate $\left(\mathrm{PO}_{4}\right)$ concentration had a similar temporal and spatial pattern to the $\mathrm{NO}_{3}$ concentration (Fig. 3).

The abundance of total diatoms in the surface waters on May 7, Jul 22, and Sep 1 was $\geq 2,000$ cells $\mathrm{mL}^{-1}$, while on the other sampling dates was $<500$ cells $\mathrm{mL}^{-1}$ (Fig. 4). The high abundance of total diatoms was mainly recorded in the waters of the inner stations of the middle area. The most dominant diatom species during blooms were $\mathrm{Eu}$ campia zodiacus on May 7, Chaetoceros curvisetus on Jul 22, and Skeletonema costatum on Sep 1. In addition, the red tides dominated by the phototrophic dinoflagellates P. donghaiense, C. furca, A. fraterculus, and C. polykrikoides occurred in a sequence (Fig. 4).P. donghaiense red tide patches were found at the inner and outer stations of the western area from Jun 12 to Jul 1; C. furca red tide patches were found at the inner stations of the middle area from Jul 11 to Aug 21; A. fraterculus red tide patches were found at the inner stations of the middle area on Aug 21; $C$. polykrikoides red tide patches were found in the western area on Aug 21, but extended to the middle and eastern areas from Sep 1. C. polykrikoides red tide patches were recorded on Oct 9 , but disappeared on Nov 10. Thus, $P$. donghaiense, C. furca, A. fraterculus, and C. polykrikoides had different temporal and spatial distributions in the study area (Fig. 4).

The vegetative cells of $C$. polykrikoides were found as early as May 7 (highest abundance $=$ approximately 10 cells $\mathrm{mL}^{-1}$ ) and on other dates including Nov 10 (highest abundance $=6$ cells $\mathrm{mL}^{-1}$ ). Furthermore, during the study period, the vegetative cells were observed at depths of 0-50 m. On Sep 1, dense C. polykrikoides patches (abundance $=$ approximately 280 cells $\mathrm{mL}^{-1}$ ) were also recorded as deep as $40 \mathrm{~m}$. Moreover, the WT and salinity ranges at which vegetative cells of $C$. polykrikoides were observed were $13.6-26.6^{\circ} \mathrm{C}$ and $27.3-34.8$, respectively, while that of $\mathrm{NO}_{3}$ and $\mathrm{PO}_{4}$ was 0-19.0 and 0-1.7 $\mu \mathrm{M}$, respectively. Furthermore, the WT and salinity range at which the abundance of C. polykrikoides was $>300$ cells $\mathrm{mL}^{-1}$ (i.e., formation of a red tide patch) was $22.2-24.4^{\circ} \mathrm{C}$ and 28.7 32.7, while that of $\mathrm{NO}_{3}$ and $\mathrm{PO}_{4}$ was 0.2-4.8 and 0-0.3 $\mu \mathrm{M}$, respectively.

\section{Relationships among temperature, salinity, and $\mathrm{NO}_{3}$ concentrations}

To identify water masses in the study areas, the relationships among WT, salinity, and nitrate $\left(\mathrm{NO}_{3}\right)$ concentration in the sampled waters ( $\mathrm{n}=277$ for each cruise) were explored (Figs 5 \& 6). On May 7, the ranges of WT and salinity were relatively small $\left(13.6-16.9^{\circ} \mathrm{C}\right.$ and $33.3-$ 34.3, respectively) (Fig. 5). However, the range of WT became wider from May 21 to Jul 11, while that of salinity did not markedly change. However, the ranges of WT and salinity became largely wider on Jul 22 to Sep 28 . Based on WT-salinity diagrams, three different water masses (i.e., warm waters with low salinity, cold waters with high salinity, and intermediate WT waters with intermediate salinity) were simultaneously observed on Aug 6, Aug 21, and Sep 28 (Fig. 5). Moreover, cold waters with high salinity and intermediate WT waters with intermediate salinity were found on Aug 13. However, the ranges of WT and salinity became narrower on Oct 9 and Nov 10 .

The ranges of salinity and $\mathrm{NO}_{3}$ from May 7 to Jul 11, with the exception of Jun 12, were relatively small (32.534.4 and $0-5.1 \mu \mathrm{M}$ ) (Fig. 6). However, the ranges of salinity and / or $\mathrm{NO}_{3}$ from Aug 6 to 21 became wider and three different water masses (i.e., highly eutrophic waters with low salinity, moderate eutrophic waters with high salinity, and moderate eutrophic waters with intermediate salinity) were observed during this period (Fig. 6).

When combining WT, salinity, and $\mathrm{NO}_{3}$ data, from Aug 6 to 21 , three different types of water masses (i.e., highly eutrophic warm waters with low salinity, moderate cold eutrophic waters with high salinity, and waters with intermediate WT, salinity, and $\mathrm{NO}_{3}$ ) were observed.

\section{Temporal variations in physical, chemical, and biological properties}

The depth of all stations ranged between 8-54 m with an averaged depth of $27 \mathrm{~m}$ (Fig. 1). The averaged surface water temperature (ASWT) at all stations increased from $16^{\circ} \mathrm{C}$ on May 7 to $25^{\circ} \mathrm{C}$ on Aug 6, while the averaged bottom water temperature (ABWT) increased from $15^{\circ} \mathrm{C}$ on May 7 to $22^{\circ} \mathrm{C}$ between Jul 22 and Sep 1 (Fig. 7A). ASWT was considerably greater than ABWT from Jul 22 to Aug 21. The average thermocline depth (ATD) at all stations was between 1 and $14 \mathrm{~m}$ (Fig. 7B).

The precipitation for 7 days (Prec-7d) in Goheung, prior to each cruise ranged from 0 to $393 \mathrm{~mm}$ (Fig. 7C). The highest Prec-7d was observed on Aug 6 and the Prec-7d on Jun 5, Jul 22, Aug 21, and Sep 28 was 94-143 mm. Fur- 


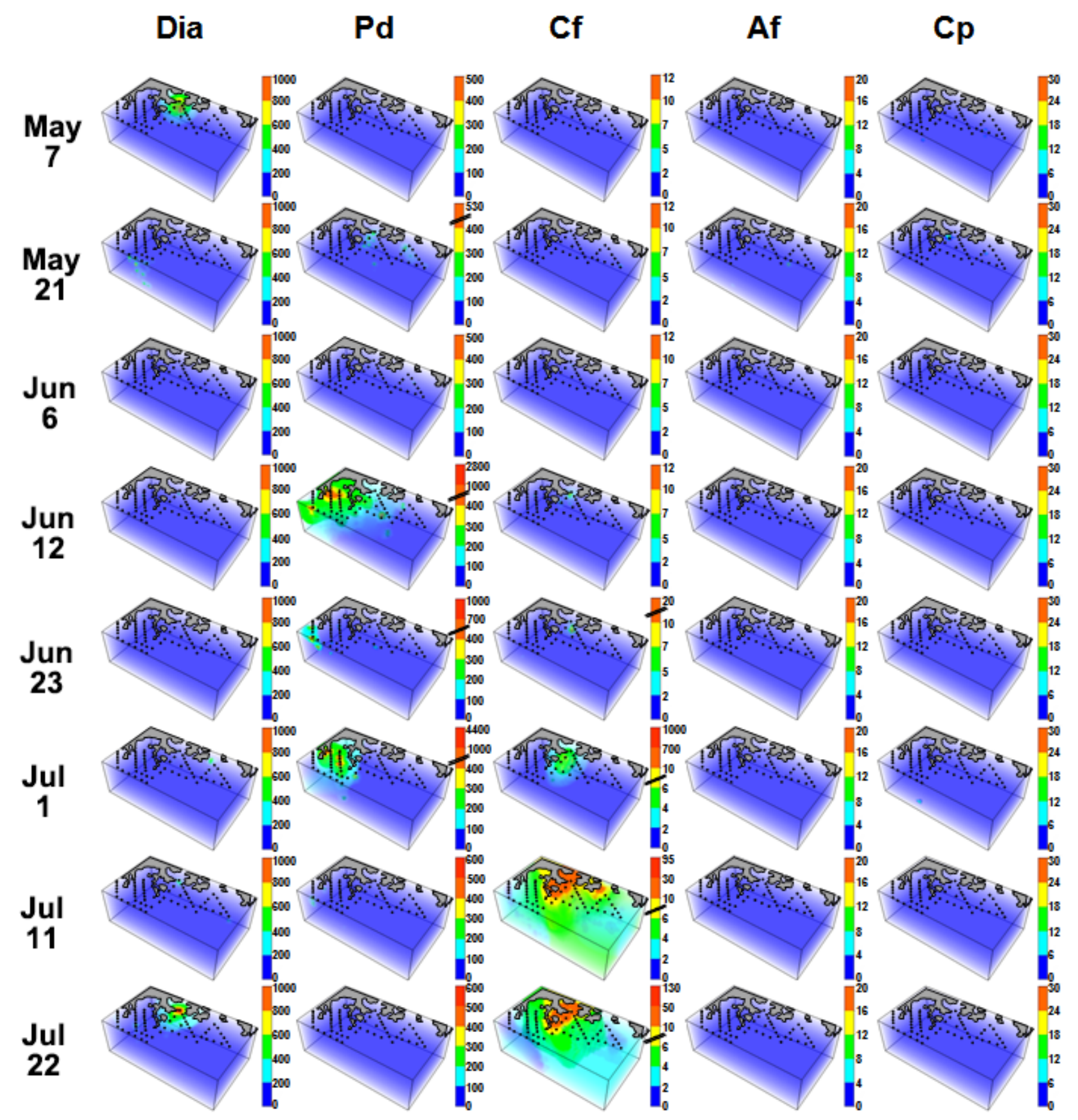

Fig. 4. Three-dimensional distributions (cells $\mathrm{mL}^{-1}$ ) of total diatoms (Dia), Prorocentrum donghaiense (Pd), Ceratium furca (Cf), Alexandrium fraterculus (Af), and Cochlodinium polykrikoides (Cp) in the study area at each cruise from May 7 to Nov 11, 2014. 


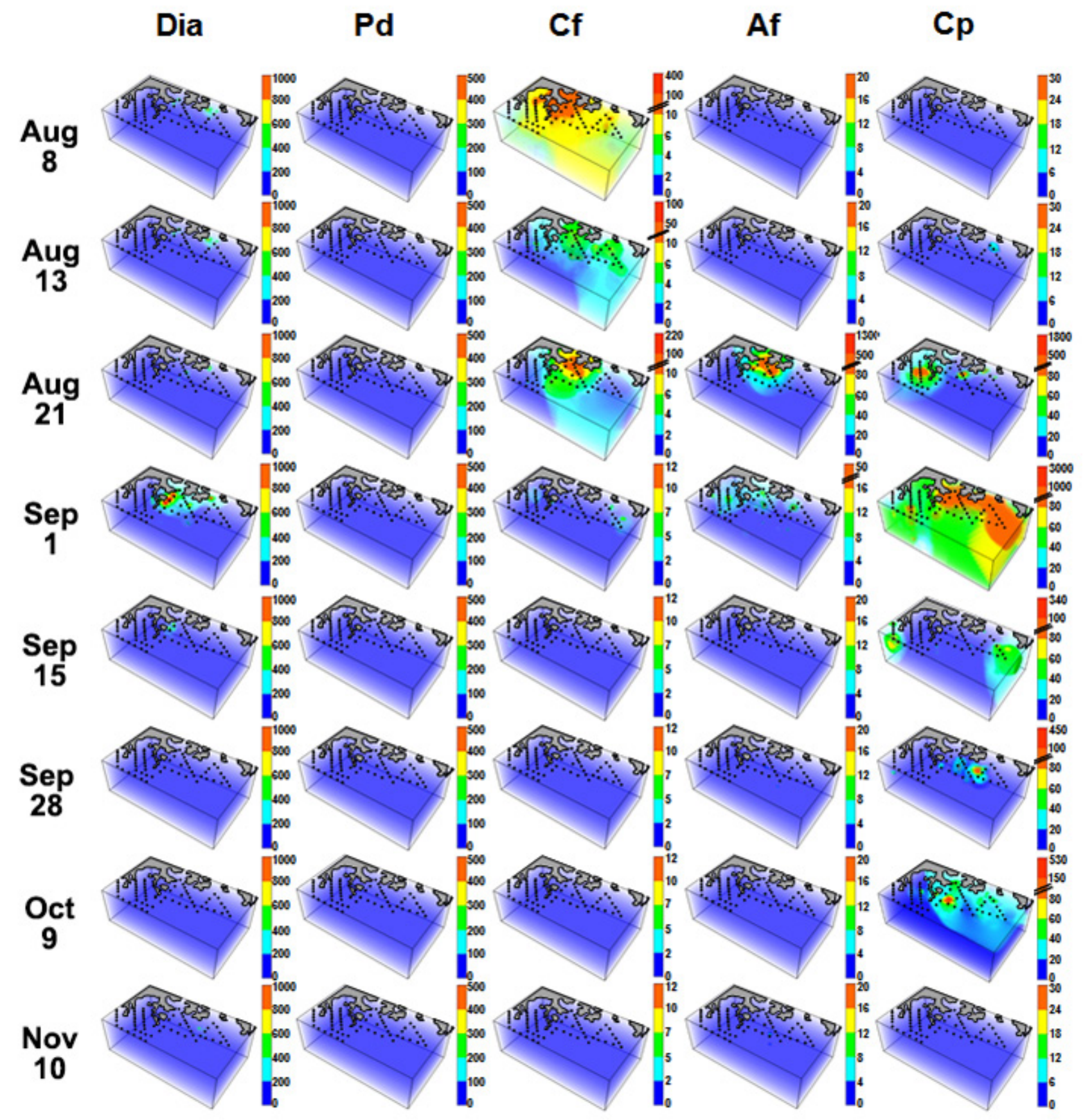

Fig. 4. Continued. 

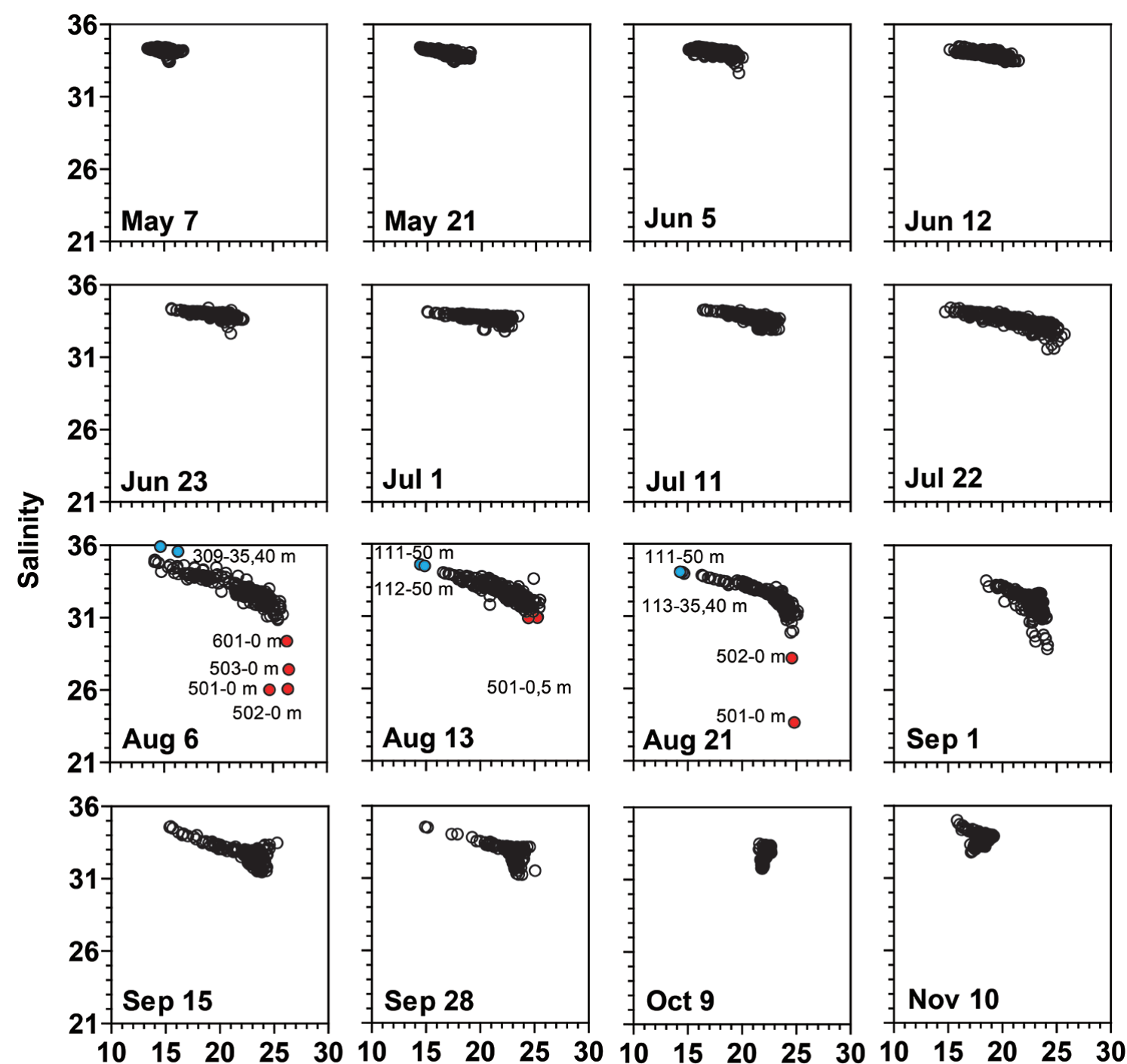

Water temperature $\left({ }^{\circ} \mathrm{C}\right)$

Fig. 5. Water temperature (WT)-salinity diagram at each cruise from May 7 to Nov 11, 2014. $n=277$ for each cruise. Red circles indicate water masses having high WT and low salinity (i.e., waters affected by freshwater). Blue circles indicate water masses having low WT and high salinity (i.e., intruded deep cold saline waters). 

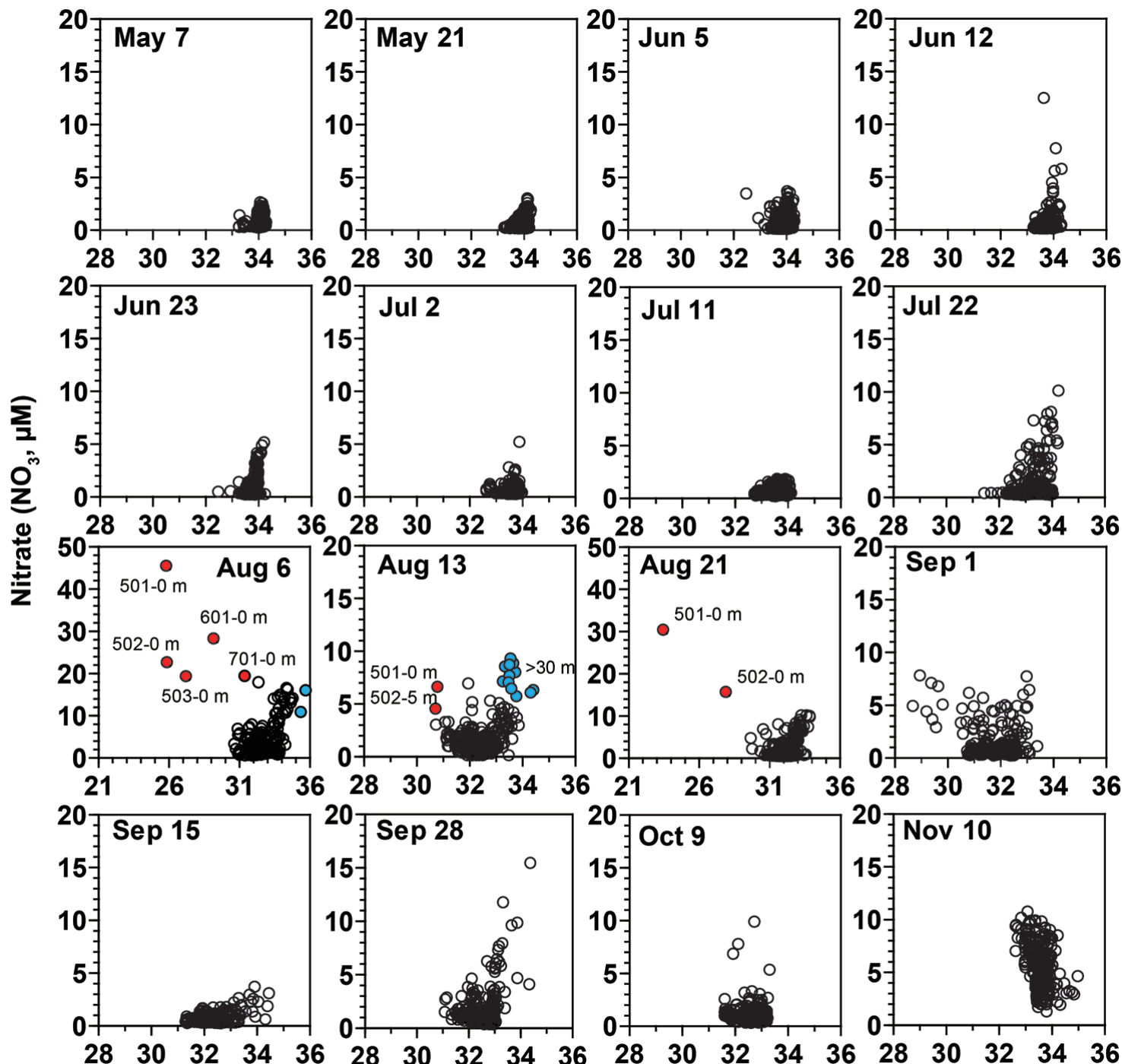

Salinity

Fig. 6. Salinity-nitrate $\left(\mathrm{NO}_{3}\right)$ concentration diagram at each cruise from May 7 to Nov 11, 2014. $\mathrm{n}=277$ for each cruise. Red circles indicate water masses having low salinity and high $\mathrm{NO}_{3}$ (i.e., waters affected by eutrophic freshwater). Blue circles indicate water masses having high salinity and high $\mathrm{NO}_{3}$ (i.e., intruded deep cold eutrophic waters). 
thermore, the Prec-7d in Tongyoung ranged from 0 to 297 mm (Fig. 7C). The highest Prec-7d was observed on Aug 21, the second highest on Aug 6 (196 mm), and the Prec$7 \mathrm{~d}$ on Jun 12, Jul 22, and Sep 28 was 43-67 mm.

The average salinity (AS) in surface waters at all stations was 34 from May 7 to Jul 1, decreased down to 31-32 between Aug 6 and Sep 28, but gradually increased up to 34 (Fig. 7D). However, the AS in deep waters was 34 on May 7 to Jul 22, decreased down to 32 on Sep 1, but gradually increased up to 34 on Nov 10.

The average nitrate concentration $\left(\mathrm{ANO}_{3}\right)$ in surface waters at all stations was $0.2-0.6 \mu \mathrm{M}$ from May 7 to Jul 22 , largely increased to $3.8 \mu \mathrm{M}$ on Aug 6, decreased again down to 0.4-1.4 $\mu \mathrm{M}$ from Aug 13 to Oct 9, but increased up to $5.9 \mu \mathrm{M}$ on Nov 10 (Fig. 7E). However, the $\mathrm{ANO}_{3}$ in deep waters was 0.6-1.4 $\mu \mathrm{M}$ from May 7 to Jul 11, slightly increased to $5.3 \mu \mathrm{M}$ on Aug 6, decreased again down to 1 $\mu \mathrm{M}$ on Sep 16, but increased up to $5.6 \mu \mathrm{M}$ on Nov 10.

The average phosphate concentration $\left(\mathrm{APO}_{4}\right)$ in surface waters at all stations was $<0.1 \mu \mathrm{M}$ from May 7 to Jul 22, but largely increased to $0.3 \mu \mathrm{M}$ on Aug 6 and to 0.1-0.2 $\mu \mathrm{M}$ from Aug 13 to Oct 9 , but increased to $0.4 \mu \mathrm{M}$ on Nov 10 (Fig. 7F). However, $\mathrm{APO}_{4}$ in the deep waters was 0.1-0.2 $\mu \mathrm{M}$ from May 7 to Jul 11, increased to $0.4 \mu \mathrm{M}$ on Aug 21, decreased down to $0.2 \mu \mathrm{M}$ on Oct 9 , but slightly increased to $0.4 \mu \mathrm{M}$ on Nov 10 .

During the study period, 119 diatom species, 41 phototrophic dinoflagellate species, 2 raphidophyte species, 3 cryptophyte species, 1 euglenophyte species, and 1 mixotrophic ciliate were recorded (Appendix 1). During the study period, diatoms (mainly E. zodiacus, C. curvisetus, and $S$. costatum) and the phototrophic dinoflagellates $P$. donghaiense, C. furca, A. fraterculus, and C. polykrikoides causing red tides (discolored) or blooms (abundant or discolored), were recorded. The highest abundance of total diatoms at all stations at each cruise was 13,020 cells $\mathrm{mL}^{-1}$ on May 7, 3,150 cell $\mathrm{mL}^{-1}$ on Jul 22, and 3,340 cells $\mathrm{mL}^{-1}$ on Sep 1, but 110-1,160 cells $\mathrm{mL}^{-1}$ at the other cruises (Fig. 7G). In addition, P. donghaiense was abundant from Jun 12 to Jul 1 (highest abundance $=4,370$ cells $\mathrm{mL}^{-1}$ ), $C$. furca from Jul 11 to Aug 21 (400 cells $\mathrm{mL}^{-1}$ ), A. fraterculus on Aug 21 (1,300 cells $\left.\mathrm{mL}^{-1}\right)$, and C. polykrikoides from Aug 21 to Oct 9 (3,000 cells mL $\left.{ }^{-1}\right)$ (Fig. $7 \mathrm{H}-\mathrm{K}$ ).

The depth of the IWMS ranged between 8-20 $\mathrm{m}$ and the averaged depth was $13 \mathrm{~m}$ (Fig. 1). The ASWT at IWMS increased from $16^{\circ} \mathrm{C}$ on May 7 to $26^{\circ} \mathrm{C}$ on Aug 6 , while the ABWT increased from $15^{\circ} \mathrm{C}$ on May 7 to $24^{\circ} \mathrm{C}$ between Jul 22 and Aug 21 (Fig. 7A). ASWT and ABWT were similar from May 7 to Jun 12 and from Sep 28 to Nov 10. However, ABWT at the other sampling times was slightly lower than
ASWT. The ATD at the IWMS was 0-7 m (Fig. 7B).

The Prec-7d in Goheung just before each cruise ranged from 0 to $393 \mathrm{~mm}$ (Fig. 7C). The highest Prec-7d was observed on Aug 6 and the Prec-7d on Jun 5, Jul 22, Aug 21, and Sep 28 were $94-143 \mathrm{~mm}$.

The AS in the surface waters at the IWMS was 33-34 from May 7 to Jul 11, decreased down to 29 on Aug 6 and 21, but gradually increased up to 33 (Fig. 7D). However, the AS in the deep waters was 33-34 on May 7 to Jul 22, decreased down to 31 on Sep 1, but gradually increased up to 33 on Nov 10.

The $\mathrm{ANO}_{3}$ in the surface waters at the IWMS was $0-1$ $\mu \mathrm{M}$ from May 7 to Jul 22, largely increased to $18 \mu \mathrm{M}$ on Aug 6 and to $8 \mu \mathrm{M}$ on Aug 21, decreased again down to 1 $\mu \mathrm{M}$ from Sep 1 to Oct 9, but increased up to $7 \mu \mathrm{M}$ on Nov 10 (Fig. 7E). However, the $\mathrm{ANO}_{3}$ in the deep waters was 0-1 $\mu \mathrm{M}$ on May 7 to Jul 22, slightly increased to 2-4 $\mu \mathrm{M}$ from Aug 6 to 21, decreased again down to $1 \mu \mathrm{M}$ from Sep 1 to Oct 9, but increased up to $6 \mu \mathrm{M}$ on Nov 10 .

The $\mathrm{APO}_{4}$ in the surface waters at the IWMS was $<0.2$ $\mu \mathrm{M}$ from May 7 to Jul 22, but largely increased to $0.6 \mu \mathrm{M}$ on Aug 6 and to 0.2-0.3 $\mu \mathrm{M}$ from Aug 21 to Oct 9, but increased to $0.5 \mu \mathrm{M}$ on Nov 10 (Fig. 7F). However, the $\mathrm{APO}_{4}$ in the deep waters was 0.1-0.3 $\mu \mathrm{M}$ from May 7 to Oct 9, but slightly increased to $0.5 \mu \mathrm{M}$ on Nov 10 .

The highest abundance of total diatoms at the IWMS at each cruise was 13,020 cells $\mathrm{mL}^{-1}$ on May 7, 3,150 cells $\mathrm{mL}^{-1}$ on Jul 22, and 2,550 cells $\mathrm{mL}^{-1}$ on Sep 1, but 62-935 cells $\mathrm{mL}^{-1}$ at the other cruises (Fig. $7 \mathrm{G}$ ). In addition, $P$. donghaiense was abundant from Jun 12 to Jul 1 (highest abundance $=1,200$ cells $\mathrm{mL}^{-1}$ ), the phototrophic dinoflagellate C. furca from Aug 6 to 21 (400 cells $\mathrm{mL}^{-1}$ ), A. fraterculus on Aug 21 (1,300 cells $\left.\mathrm{mL}^{-1}\right)$, and C. polykrikoides from Sep 1 to Oct 9 (140 cells $\left.\mathrm{mL}^{-1}\right)$ (Fig. $7 \mathrm{H}-\mathrm{K}$ ).

The depth of in IES ranged between 16-25 $\mathrm{m}$ and the averaged depth was $22 \mathrm{~m}$ (Fig. 1). The ASWT at the IES increased from $16^{\circ} \mathrm{C}$ on May 7 to $25^{\circ} \mathrm{C}$ on Aug 13 , but decreased down to $19^{\circ} \mathrm{C}$ on Nov 10 (Fig. 7A). However, the ABWT increased from $14^{\circ} \mathrm{C}$ on May 7 to $23^{\circ} \mathrm{C}$ on Sep 28, but decreased to $19^{\circ} \mathrm{C}$ on Nov 10 .

A thermocline at the IES was not formed on May 7 and from Sep 28 to Nov 10 (Fig. 7B). The ATD largely fluctuated; they were positioned at 14-17 m on Jun 12, Aug 6, and Sep 15, but at $<10 \mathrm{~m}$ from May 21 to Jun 5, Jun 23 to Jul 22, and Aug 21 (Fig. 7B).

The Prec-7d in Tongyoung just before each cruise conducted ranged from 0 to $297 \mathrm{~mm}$ (Fig. 7C). The highest Prec-7d was observed on Aug 21, the second highest Prec7d on Aug 6 (196 mm), and Prec-7d on Jun 12, Jul 22, and Sep 28 were $43-67 \mathrm{~mm}$. 

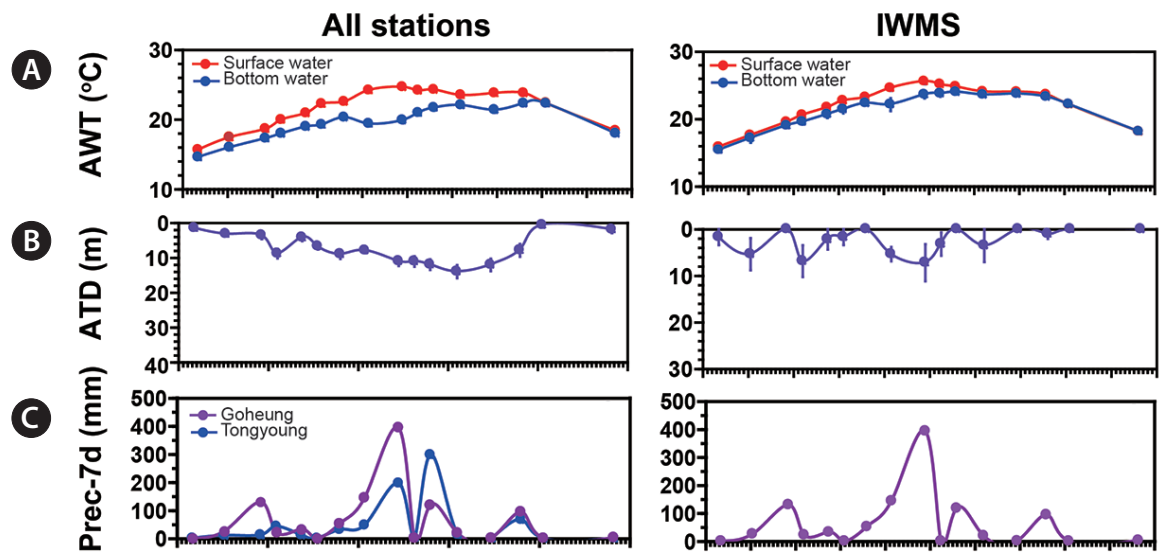

(D)
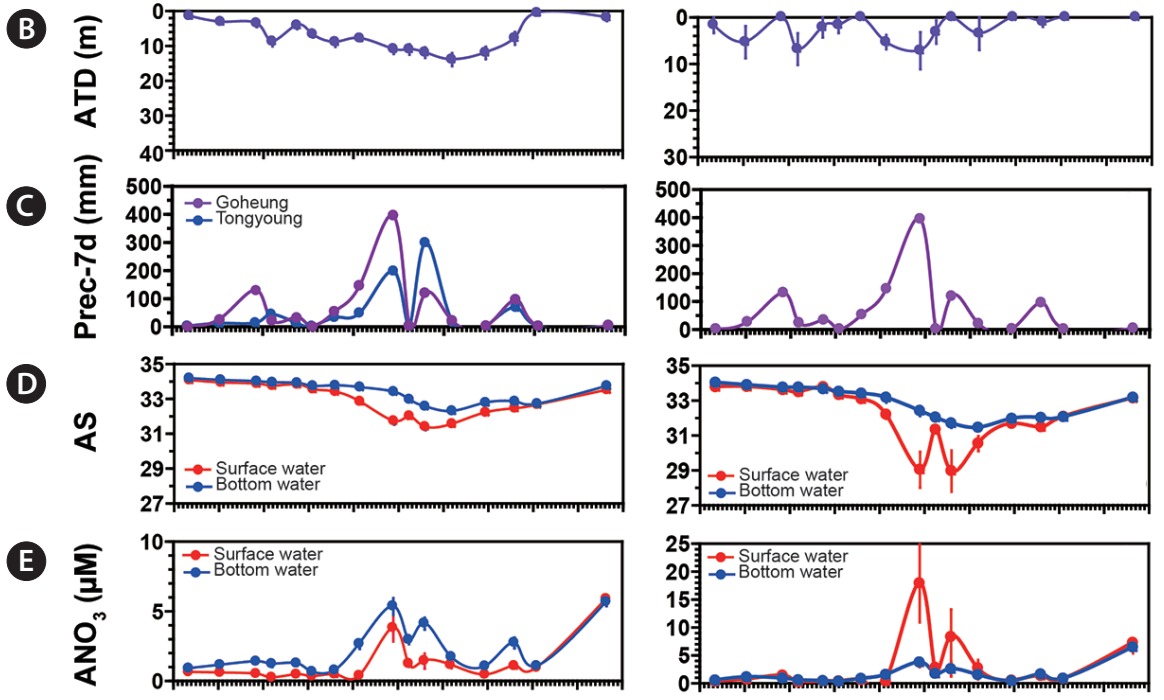

F
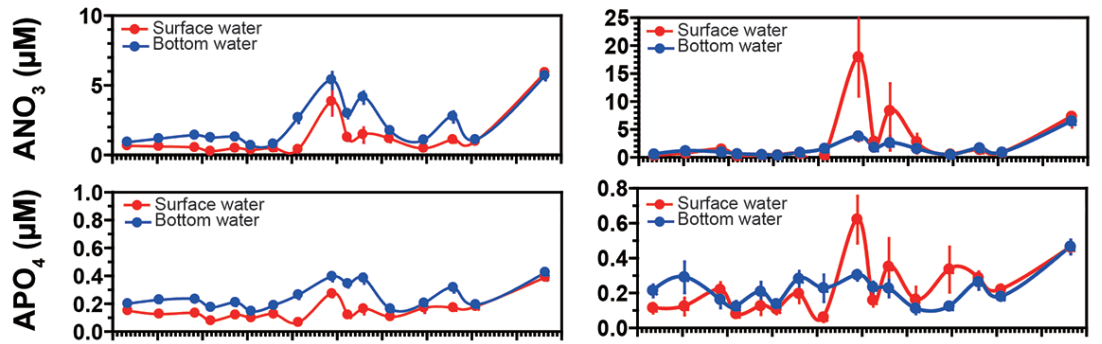

G
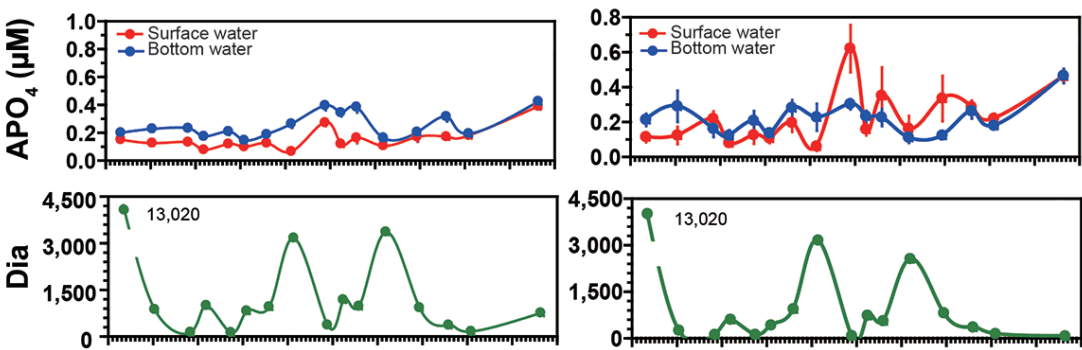

H
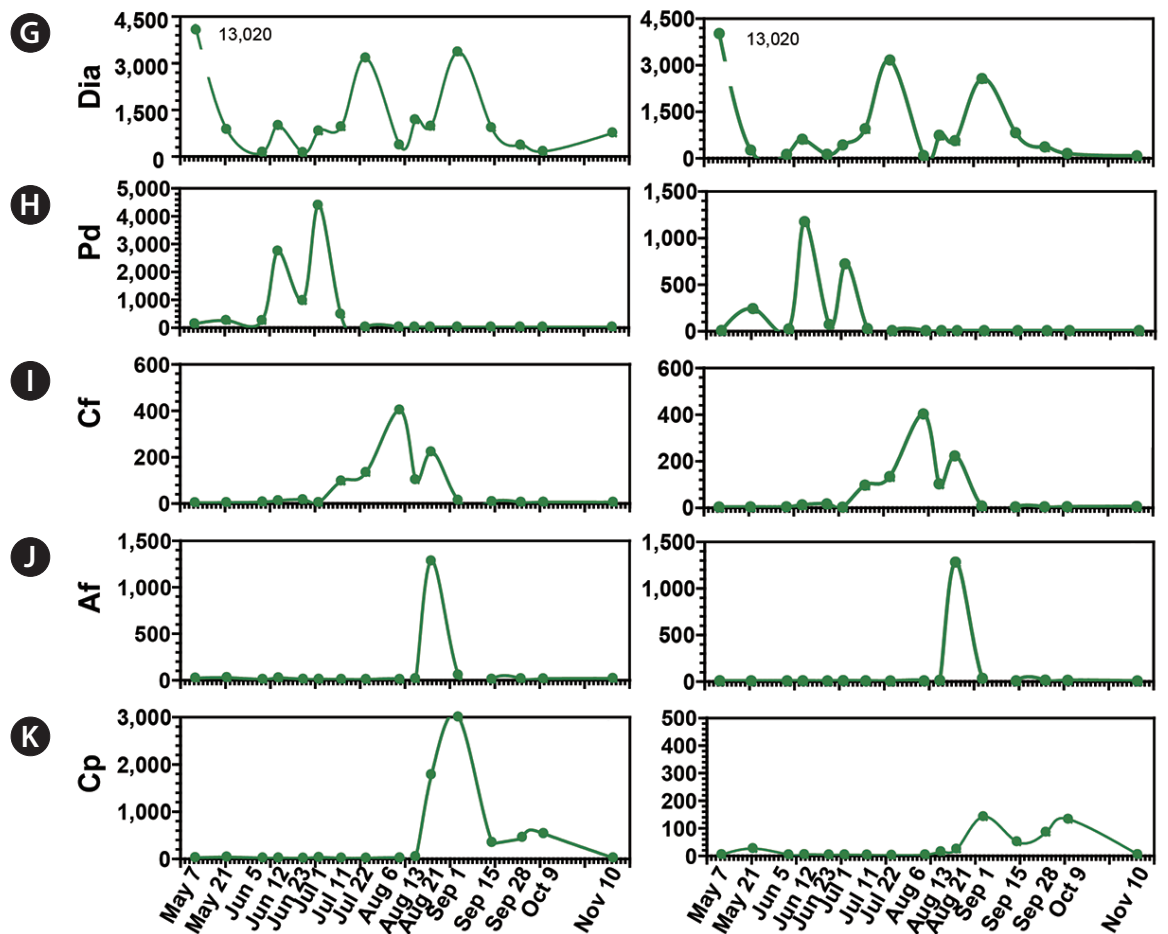

\section{Date}

Fig. 7. Physical and chemical parameters and the abundances of dominant red-tide species at all stations, the inner stations of the western and middle areas (IWMS), the eastern area (IES), and the outer stations (OTS) of the South Sea of Korea from May 7 to Nov 11, 2014. (A) Average water temperatures (AWT, ${ }^{\circ} \mathrm{C}$ ). (B) Average thermocline depth (ATD, $\mathrm{m}$ ). (C) Precipitation summed for 7 days just before each cruise was conducted (Prec-7d, mm). (D) Average salinity (AS). (E) Average nitrate concentration $\left(\mathrm{ANO}_{3}, \mu \mathrm{M}\right)$. (F) Average phosphate concentration $\left(\mathrm{APO} \mathrm{P}_{4}, \mu \mathrm{M}\right)$. Maximum abundances (cells $\mathrm{mL}^{-1}$ ) of total diatoms (Dia) (G), Prorocentrum donghaiense (Pd) (H), Ceratium furca (Cf) (I), Alexandrium fraterculus (Af) (J), and Cochlodinium polykrikoides (Cp) (K) at each cruise. The symbols in (A), (B), and (D-F) represent mean \pm standard error, but those in (G-K) represent highest abundance of each species at each cruise. 
A

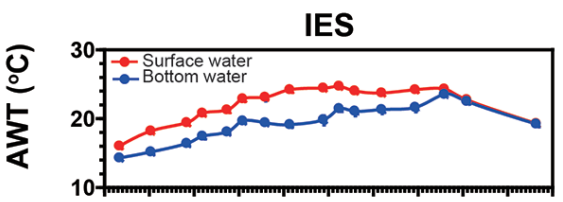

B

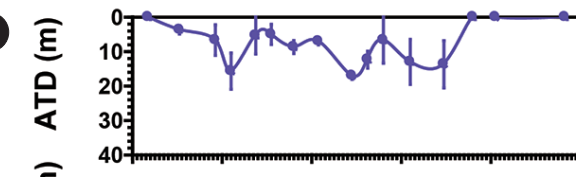

C

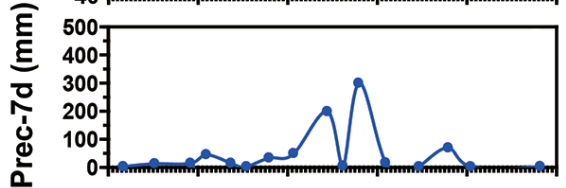

D

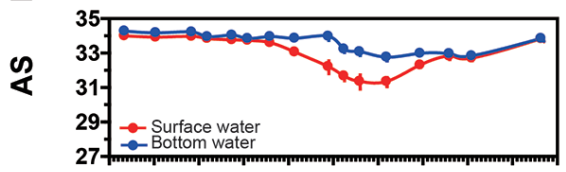

()

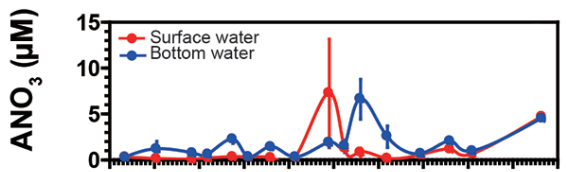

(C)

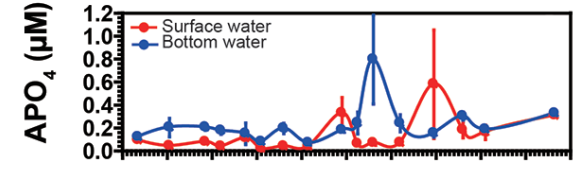

G
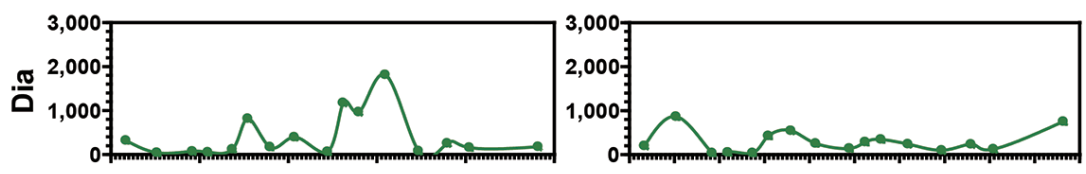

(H)

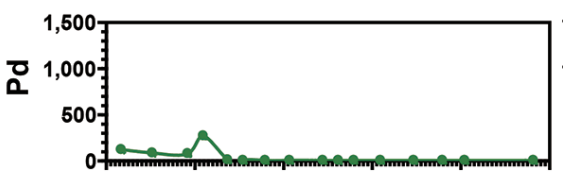

(I)

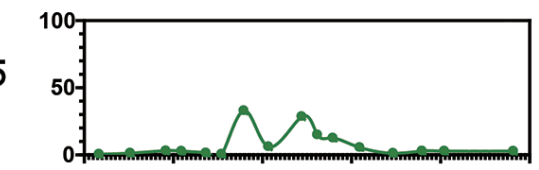

(1)
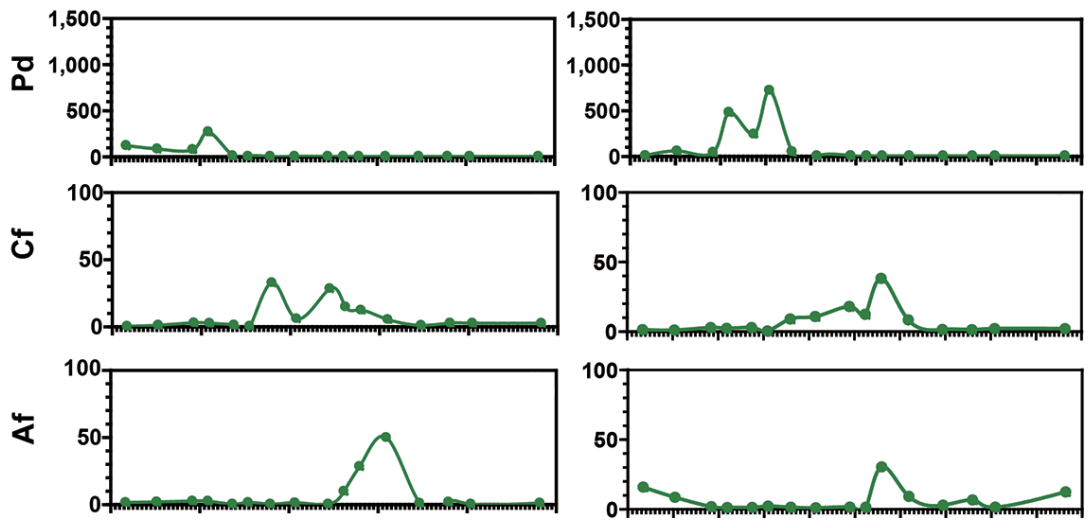

K
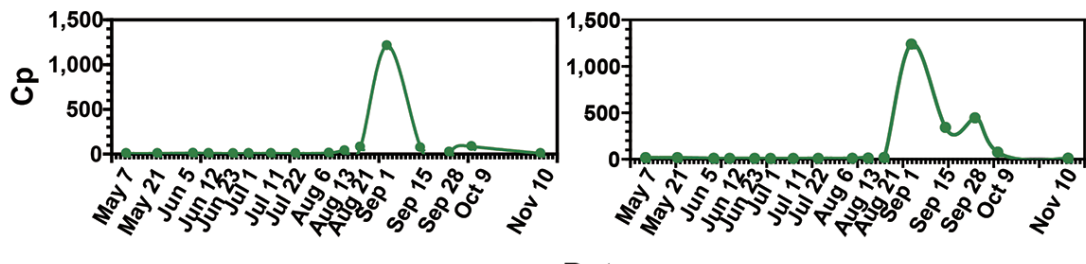

Fig. 7. Continued.

\section{Date}


The AS in the surface waters at the IES slightly decreased from 34 on May 7 to 31 on Aug 21-Sep 1, but gradually increased to 34 (Fig. 7D). However, the AS in the deep waters were 34 from May 7 to Aug 6, decreased from 34 on Aug 6 to 33 on Sep 1, but increased to 34 on Nov 10.

The $\mathrm{ANO}_{3}$ in the surface waters at the IES were $0-1 \mu \mathrm{M}$ from May 7 to Jul 22, but increased to $7 \mu \mathrm{M}$ on Aug 6 (Fig. 7E). Furthermore, the $\mathrm{ANO}_{3}$ in the deep waters was 0-2 $\mu \mathrm{M}$ on May 7 to Jul 22, increased to $7 \mu \mathrm{M}$ on Aug 21, decreased to $0-2 \mu \mathrm{M}$ on Sep 16-Oct 9, but increased to $5 \mu \mathrm{M}$ on Nov 10.

The $\mathrm{APO}_{4}$ in the surface waters at the IES was 0-0.2 $\mu \mathrm{M}$ with two peaks of 0.3-0.6 $\mu \mathrm{M}$ on Aug 6 and Sep 15 (Fig. 7F). However, $\mathrm{APO}_{4}$ in the deep waters was 0.1-0.3 $\mu \mathrm{M}$ with a peak of $0.8 \mu \mathrm{M}$ on Aug 21 .

During the study period, the maximum abundances of total diatoms at the IES were $>1,000$ cells $\mathrm{mL}^{-1}$ from Aug 13 to Sep 1, but $<1,000$ cells $\mathrm{mL}^{-1}$ in the other cruises (Fig. 7G). In addition, the maximum abundance of $P$. donghaiense was 270 cells $\mathrm{mL}^{-1}$ on Jun 12 , but $<10$ cells $\mathrm{mL}^{-1}$ from Jun 23 to Nov 10 (Fig. $7 \mathrm{H}$ ). Furthermore, the maximum abundances of $C$. furca were $10-30$ cells $\mathrm{mL}^{-1}$ from Jul 11 to Aug 21 except Jul 22 (Fig. 7I). The maximum abundance of $A$. fraterculus was 50 cells $\mathrm{mL}^{-1}$ on Sep 1 (Fig. 7J). The maximum abundance of C. polykrikoides was 1,200 cells $\mathrm{mL}^{-1}$ on Sep 1 , but $<10$ cells $\mathrm{mL}^{-1}$ from May 7 to Aug 6 (Fig. $7 \mathrm{~K}$ ).

The depths of OTS were 27-54 $\mathrm{m}$ and the averaged depth was $38 \mathrm{~m}$ (Fig. 1). The ASWT at the OTS increased from $15^{\circ} \mathrm{C}$ on May 7 to $24^{\circ} \mathrm{C}$ on Aug 13, but decreased down to $19^{\circ} \mathrm{C}$ on Nov 10 (Fig. 7A). However, the ABWT increased from $14^{\circ} \mathrm{C}$ on May 7 to $21^{\circ} \mathrm{C}$ on Sep $1,22^{\circ} \mathrm{C}$ on Oct 9 , but decreased to $18^{\circ} \mathrm{C}$ on Nov 10 .

The ATD at the OTS was $2 \mathrm{~m}$ on May 7, increased to 27 $\mathrm{m}$ on Sep 1 with a fluctuation, but decreased to $3 \mathrm{~m}$ on Oct 9 (Fig. 7B).

The pattern in the Prec-7d in Goheung was similar to that in Tongyoung, but magnitudes were different (Fig. 7C).

The AS in the surface waters at the OTS slightly decreased from 34 on May 7 to 32 on Aug 6-Sep 1, but gradually increased to 34 (Fig. 7D). However, the AS in the deep waters were 34 from May 7 to Aug 13 and on Nov 10, but 33 from Aug 21 to Oct 9.

The $\mathrm{ANO}_{3}$ in the surface waters at the OTS was $0-1 \mu \mathrm{M}$ from May 7 to Oct 9, but $4 \mu \mathrm{M}$ on Nov 10 (Fig. 7E). However, the $\mathrm{ANO}_{3}$ in the deep waters was $0-1 \mu \mathrm{M}$ on May 7 to Jul 22 , increased to 5-8 $\mu \mathrm{M}$ on Aug 6 to Aug 21, but decreased to 1-4 $\mu \mathrm{M}$ from Sep 1 to Nov 10. The ranges of $\mathrm{ANO}_{3}$ on Aug 6 and Sep 1 were 1-16 and 0-7 $\mu \mathrm{M}$, respectively.
The $\mathrm{APO}_{4}$ in the surface waters at the OTS was 0-0.3 $\mu \mathrm{M}$ with peaks on Aug 6 and 21, and Nov 10 (Fig. 7F). However, $\mathrm{APO}_{4}$ in the bottom waters was $0.1-0.3 \mu \mathrm{M}$ on May 7 to Jul 22 and Sep 1 to 15, but $0.5 \mu \mathrm{M}$ on Aug 6 to 21 .

During the study period, the red tides dominated by each of $P$. donghaiense and $C$. polykrikoides occurred at the OTS (Fig. 7G-K). During the study period, the maximum abundances of total diatoms at the OTSs were 530850 cells $\mathrm{mL}^{-1}$ on May 21, Jul 11, and Nov 10, but $<500$ cells $\mathrm{mL}^{-1}$ in the other cruises (Fig. $7 \mathrm{G}$ ). In addition, the maximum abundance of $P$. donghaiense was $>200$ cells $\mathrm{mL}^{-1}$ from Jun 12 to Jul 1 , but $<100$ cells $\mathrm{mL}^{-1}$ in the other cruises (Fig. 7H). Furthermore, the maximum abundances of C. furca and A. fraterculus were 40 and 30 cells $\mathrm{mL}^{-1}$, respectively, on Aug 21 (Fig. 7I \& J). The maximum abundances of $C$. polykrikoides were $\leq 10$ cells $\mathrm{mL}^{-1}$ from May 7 to Aug 21, 1,230 cells $\mathrm{mL}^{-1}$ on Sep 1,335-440 cells $\mathrm{mL}^{-1}$ on Sep 15 and 28, but 69 and 3 cells $\mathrm{mL}^{-1}$ on Oct 9 and Nov 10 (Fig. 7K).

\section{DISCUSSION}

\section{Temporal variations in the 3-D distributions of red tide species and environmental factors}

In this study, the investigation of 3-D distributions of phytoplankton, including red tide species and environmental parameters before, during, and after the outbreak of C. polykrikoides red tides in the South Sea of Korea provided several important results. The results indicate some distinct patterns in red tide events during 2014: 1) the red tides caused by the phototrophic dinoflagellates $P$. donghaiense, C. furca, A. fraterculus, and C. polykrikoides occurred in sequence, while red tides caused by diatoms occurred without a certain clear pattern; 2) C. furca, and A. fraterculus red tides occurred mainly at the inner stations, while those of $P$. donghaiense and C. polykrikoides occurred at both inner and OTSs; 3) C. polykrikoides red tide patches were found at the OTS when thermocline depths were $>20 \mathrm{~m}$ with the retreat of the deep cold waters. The analysis of data on the occurrence of red tides in the South Sea of Korea from 1985 to 2013, provided by the National Fisheries Research and Development Institute (NFRDI, http://www.nifs.go.kr/portal/redtideInfo), produced a similar sequence during the years in which C. polykrikoides red tides occurred. In general, Prorocentrum spp. red tides (mainly $P$. donghaiense, but sometimes $P$. minimum, P. micans, or P. triestinum) occur first, C. furca or Alexandrium spp. red tides occur next, and $C$. 
polykrikoides red tides occur last (Table 2). However, red tides by one or two of the phototrophic dinoflagellates Akashiwo sanguinea, Gonyaulax polygramma, Gymnodinium spp., and Scrippsiella trochoidea sometimes occurred between Prorocentrum spp. and C. polykrikoides red tides. However, it was difficult to understand the reasons for these sequential red tide events because 3-D distributions of physical, chemical, and biological parameters were not available for the NFRDI data. The results of the present study may give some insights in understanding such patterns; the period and location of red tides caused by each of these dinoflagellates, as well as the physical and chemical conditions under which the red tides are formed differ from other species. Therefore, each of these red tide species is likely to have an advantage over competing species.

The temperatures for the optimal growth of $P$. donghaiense, C. furca, A. fraterculus, and C. polykrikoides are not very different from one another, but their $\mathrm{K}_{1 / 2}$ of $\mathrm{NO}_{3}$ uptake, maximum growth rates, and maximum swimming speeds are considerably different (Table 3); the $\mathrm{K}_{1 / 2}$ 's of $\mathrm{NO}_{3}$ uptake of P. donghaiense and C. furca (0.4-0.5 $\mu \mathrm{M})$ are lower than that of $C$. polykrikoides (2.1-2.2 $\mu \mathrm{M})$.
Thus, as the $\mathrm{NO}_{3}$ concentration increases, $P$. donghaiense and $C$. furca are likely to uptake $\mathrm{NO}_{3}$, rapidly grow, and form red tide patches earlier than C. polykrikoides. This differential $\mathrm{K}_{1 / 2}$ of $\mathrm{NO}_{3}$ uptake may be partially responsible for the earlier red tides or blooms of $P$. donghaiense and C. furca in June in which $\mathrm{NO}_{3}$ concentrations in surface waters were $<1 \mu \mathrm{M}$. Furthermore, the sequence of the maximum growth rates of these four dinoflagellates are $P$. donghaiense (approximately $\left.1.5 \mathrm{~d}^{-1}\right)>C$. furca $(1.3$ $\left.\mathrm{d}^{-1}\right)>$ A. fraterculus $\left(0.7 \mathrm{~d}^{-1}\right)>$ C. polykrikoides $\left(0.6 \mathrm{~d}^{-1}\right)$ (Fig. 8). Moreover, the maximum growth rates of most $C$. polykrikoides strains, including the strains from the South Sea of Korea are approximately $0.4 \mathrm{~d}^{-1}$. Thus, if the favorable conditions for their optimal growth are given (i.e., high $\mathrm{NO}_{3}$ concentrations following heavy rains), P. donghaiense is likely to form red tide patches or cause blooms first, C. furca and A. fraterculus next, and C. polykrikoides last as observed in this study and the NFRDI data. In general, the favorable conditions for the optimal growth of most phototrophic dinoflagellates are light abundance and eutrophic conditions. Thus, the sequence of the maximum growth rates of these four dinoflagellates may be partially responsible for the sequence of red tides in the

Table 2. Changes in red-tide causative species in the South Sea of Korea from 1985 to 2013

\begin{tabular}{|c|c|}
\hline Year & Change of red-tide species \\
\hline 1985 & Prorocentrum donghaiense - (Prorocentrum minimum) - Cochlodinium polykrikoides \\
\hline 1988 & Prorocentrum micans - C. polykrikoides \\
\hline 1989 & Prorocentrum minimum - (Gymnodinium sp.) - C. polykrikoides \\
\hline 1990 & P. donghaiense - (Gymnodinium sp.) - Ceratium sp. - Alexandrium affine-C. polykrikoides \\
\hline 1991 & P. donghaiense -Alexandrium sp. - (Akashiwo sanguinea) - C. polykrikoides \\
\hline 1993 & P. donghaiense - Ceratium furca-C. polykrikoides \\
\hline 1994 & Prorocentrum sp. - Ceratium sp. - C. polykrikoides \\
\hline 1995 & Prorocentrum sp. - C. furca - C. polykrikoides \\
\hline 1996 & P. donghaiense - C.furca - (A. sanguinea) - C. polykrikoides \\
\hline 1997 & P. donghaiense - C. furca - C. polykrikoides \\
\hline 1998 & P. donghaiense - C. furca + Prorocentrum spp. - C. polykrikoides \\
\hline 1999 & Prorocentrum sp. - C. furca - (Gymnodinium sp.) - C. polykrikoides \\
\hline 2000 & Prorocentrum sp. - (A. sanguinea) - C. furca - (P. minimum) - C. polykrikoides \\
\hline 2001 & Prorocentrum sp. - C. furca - (P. micans $)-$ C. polykrikoides \\
\hline 2002 & Prorocentrum sp. - C. polykrikoides \\
\hline 2003 & P.donghaiense - (A. sanguinea) - C. polykrikoides \\
\hline 2004 & P. donghaiense - (A. sanguinea) - P.donghaiense - C. polykrikoides \\
\hline 2005 & P.donghaiense - C. polykrikoides \\
\hline 2006 & Prorocentrum sp. - C. polykrikoides \\
\hline 2007 & P. triestinum - (A. sanguinea) - C. polykrikoides \\
\hline 2009 & P. minimum-C. furca-Alexandrium fraterculus - (Gonyaulax polygramma) - (Scrippsiella trochoidea) - C. polykrikoides \\
\hline 2010 & P. donghaiense - P. minimum - C. furca-(Gymnodinium sp.) - C. polykrikoides \\
\hline 2012 & C. furca-C. polykrikoides \\
\hline 2013 & P.donghaiense - C. polykrikoides \\
\hline
\end{tabular}

Raw data on the red tide species were obtained from the National Fisheries Research and Development Institute website (http://www.nifs.go.kr/ portal/redtidelnfo). Bold indicates the species or genera forming red tides in the present study. 


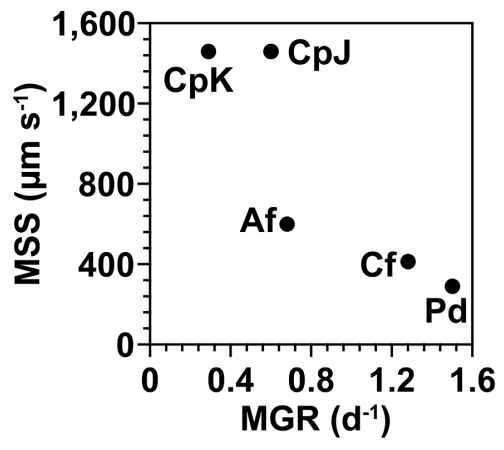

Fig. 8. Maximum swimming speed (MSS; $\mu \mathrm{m} \mathrm{s}^{-1}$ ) of the dominant red tide dinoflagellates in this study as a function of the maximum growth rates (MGR; $\mathrm{d}^{-1}$ ). Pd, Prorocentrum donghaiense; Cf, Ceratium furca; Af, Alexandrium fraterculus; CpK, Korean strain of Cochlodinium polykrikoides; CpJ, Japanese strain of C. polykrikoides.

inner stations following high nutrients input in the surface waters owing to heavy rains.

Cochlodinium red tides occurred and persisted at the OTSs when $\mathrm{NO}_{3}$ concentrations of the surface waters were $<2 \mu \mathrm{M}$ and thermocline depths were $>20 \mathrm{~m}$ with the retreat of the deep cold waters, and the abundance of the competing red-tide species reduced. In this study, C. polykrikoides formed predominant red tides at the OTSs from Sep 1 to 28. How could the slow growing $C$. polykrikoides form such red tides during this period? $P$. donghaiense, C. furca, A. fraterculus, and C. polykrikoides are able to migrate between well-lit surface waters and eutrophic deep waters and grow by acquiring nutrients from eutrophic deep waters (Jeong et al. 2015). Usually a thermocline separates the well-lit surface waters and eutrophic deep waters. Therefore, to acquire nutrients from the eutrophic deep waters, a migratory dinoflagellate should descend deeper than the thermocline. The maximum swimming speeds and reachable depth after a 10 $\mathrm{h}$ travel is considerably different between these four red tide dinoflagellates (Table 3); the maximum swimming speeds and reachable depth of C. polykrikoides (approximately $1,450 \mu \mathrm{m} \mathrm{s}^{-1}, 52 \mathrm{~m}$ ) are highest, $P$. donghaiense (280 $\left.\mu \mathrm{m} \mathrm{s}^{-1}, 10 \mathrm{~m}\right)$ lowest, and $A$. fraterculus $\left(680 \mu \mathrm{m} \mathrm{s}^{-1}, 24 \mathrm{~m}\right)$ and C. furca $\left(400 \mu \mathrm{m} \mathrm{s}^{-1}, 15 \mathrm{~m}\right)$ intermediate (Fig. 8). In this study, the vegetative cells of C. polykrikoides were observed at $50 \mathrm{~m}$ and C. polykrikoides red tide patches were also found at approximately $40 \mathrm{~m}$. Thus, this evidence suggests that C. polykrikoides may migrate down to $50 \mathrm{~m}$, as calculated. Therefore, in theory, if the thermocline depth is shallower than $10 \mathrm{~m}$, all these four dinoflagellates may reach eutrophic deep waters. Under these circumstances, the fastest growing species is likely to form red tides first and the slowest growing species last. However, if the thermocline depth is deeper than $25 \mathrm{~m}$, only C. polykrikoides can reach the eutrophic deep waters and grow, but competitors may not survive. In this study, small blooms of $A$. fraterculus and $C$. furca occurred at the OTSs when the $\mathrm{NO}_{3}$ concentrations in the surface water were $<1 \mu \mathrm{M}$, but those in the deep waters were $4-5 \mu \mathrm{M}$ and the thermocline depths were approximately $15-20 \mathrm{~m}$. Intrusion of deep cold waters was likely to shift thermoclines shallower (Fig. 9). However, Cochlodinium red tides formed and persisted at the OTSs when the surface water $\mathrm{NO}_{3}$ concentration was low and thermocline depths were $>20 \mathrm{~m}$. Prior to the outbreak of huge Cochlodinium red tides at the OTSs in Aug, the thermocline depths were approximately 15-20 m. However, they were recorded deeper, at $25 \mathrm{~m}$, on

Table 3. Comparison of eco-physiological characterizations of the phototrophic dinoflagellate species causing red tides in the present study

\begin{tabular}{llcccccl}
\hline \multicolumn{1}{c}{ Species } & \multicolumn{1}{c}{ Isolation site } & $\begin{array}{c}\text { MGR } \\
\left(\mathbf{d}^{-1}\right)\end{array}$ & $\begin{array}{c}\text { MSS } \\
\left(\mu \mathbf{m ~ s}^{-1}\right)\end{array}$ & $\begin{array}{c}\mathbf{D}_{10 \mathrm{~h}} \\
(\mathbf{m})\end{array}$ & $\begin{array}{c}\mathbf{K}_{1 / 2}\left(\mathrm{NO}_{3}\right) \\
(\mu \mathrm{M})\end{array}$ & $\begin{array}{c}\mathrm{T} \\
\left({ }^{\circ} \mathbf{C}\right)\end{array}$ & Reference \\
\hline Prorocentrum donghaiense & South Sea, Korea & - & $280^{\mathrm{a}}$ & 10 & - & - & Jeong et al. (2015) \\
& East China Sea & 1.51 & - & - & 0.4 & 27 & Xu et al. (2010), Hu et al. (2014) \\
Ceratium furca & Sagami Bay, Japan & 0.72 & $403^{\mathrm{b}}$ & 15 & 0.5 & 24 & Baek et al. (2008a, 2008b, 2009) \\
& Arabian Sea & 1.29 & - & - & 0.4 & - & Qasim et al. (1973) \\
Alexandrium fraterculus & South Sea, Korea & 0.69 & $680^{\mathrm{a}}$ & 24 & - & - & Our unpublished data, Lee et al. (2016) \\
& Sanriku coast, Japan & 0.35 & - & - & - & 25 & Lim et al. (2007a) \\
Cochlodinium polykrikoides & South Sea, Korea & 0.30 & - & - & 2.1 & 25 & Kim et al. (2001) \\
& South Sea, Korea & - & $1,449^{\mathrm{a}}$ & 52 & - & - & Jeong et al. (1999) \\
& Furue Bay, Japan & 0.41 & - & - & - & 25 & Kim et al. (2004) \\
& West Kyushu, Japan & 0.61 & - & - & - & 27 & Yamatogi et al. (2005) \\
\hline
\end{tabular}

MGR, maximum growth rate of a strain; MSS, maximum swimming speed; $D_{10 \mathrm{~h}}$, calculated depth which each red tide species can reach by descending for $10 \mathrm{~h} ; \mathrm{K}_{1 / 2}\left(\mathrm{NO}_{3}\right)$, half-saturation constants for uptake of nitrate; $\mathrm{T}$, temperature for the optimal growth of each strain. ${ }^{\mathrm{a}} \mathrm{MSS}$ and ${ }^{\mathrm{b}} \mathrm{MSS}$ were measured at 20 and $22^{\circ} \mathrm{C}$, respectively. 

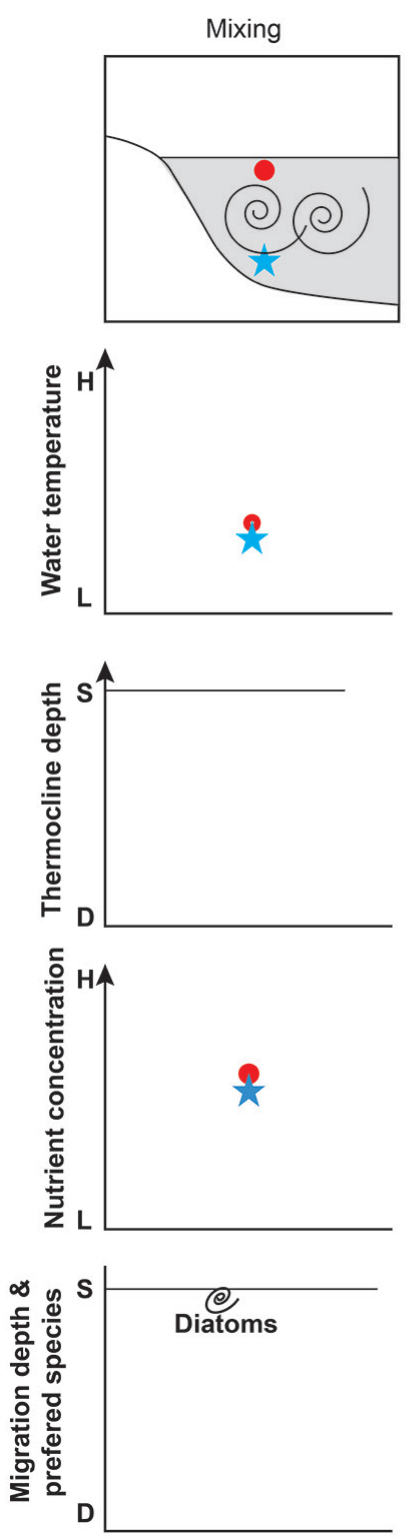

Moderate solar insolation / Intrusion of cold water
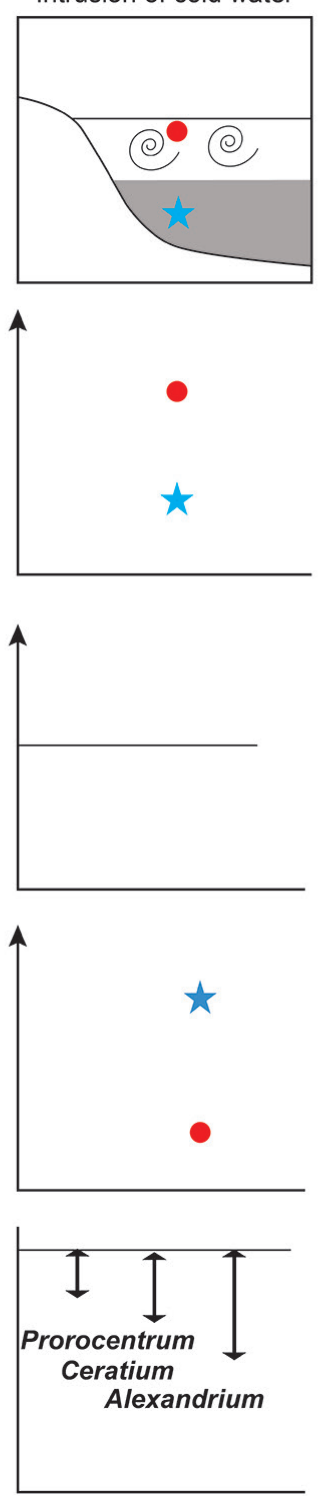

High solar insolation /

Retreat of intruded cold water
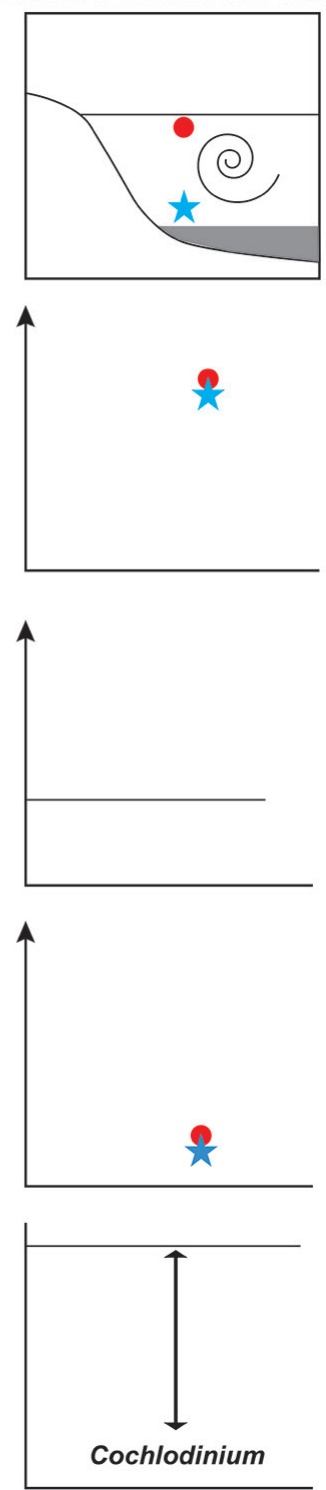

Fig. 9. Diagram showing water temperature, thermocline depth, and nutrient concentration in the surface (red) and deep (blue) waters when the water column is well mixed (left column), strongly stratified with intrusion of deep cold waters (middle column), and strongly stratified with retreat of intruded deep cold waters (right column). Preferred red tide species under each circumstance are suggested. See texts for details.

Sep 1. Retreat of the deep cold waters was likely to cause this shift of thermoclines (Fig. 9). This retreat was likely to lower $\mathrm{NO}_{3}$ concentrations in the waters of deep sampling depths at the OTSs, but the deep cold waters away from the study area was likely to still contain high nutrients (approximately $8 \mu \mathrm{M} \mathrm{NO}_{3}$ ) (Fig. 9). The Geostationary Ocean Color Imager (GOCI) satellite images on Sep 4 showed that many huge $C$. polykrikoides red tide patches existed offshore (provided by Korean Institute of Ocean Science and Technology). The Cochlodinium red tides were maintained at the OTSs until Sep 29 during which thermoclines were positioned at depths $>20 \mathrm{~m}$. Thus, the deep thermoclines formed by high solar insolation and retreat of the intruded deep cold waters at the OTSs are likely to favor Cochlodinium red tides over competing red tide species. The competing dinoflagellates that weaken or die during the period of retreat of deep cold waters may not recover completely when the intrusion of deep cold waters occurs again. The short periods of their small blooms at the OTSs may support this hypothesis (see Fig. 
7). The Cochlodinium red tides declined and disappeared on Oct 9 and Nov 10 when the thermoclines at the OTSs also almost disappeared. The sequence of the maximum swimming speeds and thus potential reachable depths may be partially responsible for the huge C. polykrikoides red tides at the OTSs following the small blooms of the other dinoflagellates. Intrusion and retreat of deep cold waters have been suggested to be affected by alternations of spring and neap tides with an approximate 15-day period (e.g., Kaneda et al. 2002). Thus, the intrusion and retreat of deep cold waters and in turn the growth of $C$. polykrikoides blooms may be predicted. It is worthwhile to explore this topic further.

During Cochlodinium red tides, the maximum abundance of total diatoms at the inner stations of the western and eastern areas was relative high, while that at the OTSs was relatively low. Some diatoms are known to inhibit the growth and migration of C. polykrikoides above a certain level of its density (Lim et al. 2014); the diatom Thalassiosira decipiens reduces the swimming speed of C. polykrikoides at diatom concentrations of $>\sim 1,000$ cells $\mathrm{mL}^{-1}$, and another diatom, Chaetoceros danicus, causes negative growth rates at concentrations of $>\sim 1,200$ cells $\mathrm{mL}^{-1}$. On Sep 1, the maximum abundance of $T$. decipiens and the other Thalassiosira species at the inner stations was approximately 1,100 cells $\mathrm{mL}^{-1}$ and that of $C$. danicus and the other Chaetoceros species was approximately 2,660 cells $\mathrm{mL}^{-1}$. Thus, at the inner stations, Thalassiosira spp. and Chaetoceros spp. may inhibit growth rate and / or swimming speed of C. polykrikoides and thus lower the abundance of $C$. polykrikoides and / or shorten $C$. polykrikoides red tide periods.

The results of this study clearly show that there were two major sources of nutrients (in particular $\mathrm{NO}_{3}$ ) in this study area; one source was the freshwater input to the inner stations through the surface from Seomjin River, Haechang Bay, and Yeoja Bay, and the other source was the deep cold waters at the OTSs. The 3-D distributions of the salinity showed that freshwater input lowers the salinity most in the middle area, followed by the western area, eastern area, and the OTSs. This pattern is likely to cause highest $\mathrm{NO}_{3}$ concentration in surface waters at the IWMS, moderate concentration in the surface waters at the IES, and the lowest concentration at the OTSs. However, the 3-D distribution of $\mathrm{NO}_{3}$ concentration showed that in the deep cold waters, highest $\mathrm{NO}_{3}$ concentrations were observed at the OTS, slightly lower concentrations at the IES, and the lowest concentrations at the IWMS. Interestingly, at the IES, a peak of $\mathrm{NO}_{3}$ concentration in the surface water driven by freshwater input occurred on
Aug 6, which was followed by a peak in the deep waters probably driven by intrusion of deep cold waters on Aug 21. The maximum $\mathrm{NO}_{3}$ concentration elevated because of freshwater input in the study area (approximately $45 \mu \mathrm{M}$ ) was greater because of deep cold water intrusion (approximately $9 \mu \mathrm{M}$ ). However, the volume of the deep cold waters containing $9 \mu \mathrm{M} \mathrm{NO}_{3}$ is likely to be greater than that of the surface waters containing $45 \mu \mathrm{M} \mathrm{NO}_{3}$ and thus the average $\mathrm{NO}_{3}$ concentrations in the bottom waters at all stations during each cruise was greater than those in the surface waters (Fig. 7). Therefore, the deep cold waters are likely to support large red tide patches. Thus, the intrusion (forth) and retreat (back) of the deep cold waters containing high nutrients may shift the thermocline shallower or deeper, affect nutrient availability for competing red tide species, and determine causative species of red tides.

The ranges of WTs and salinities at which vegetative cells of C. polykrikoides were present (approximately 14$27^{\circ} \mathrm{C}$ and $27-35$, respectively) or its red tide patches were observed $\left(22.2-24.4^{\circ} \mathrm{C}\right.$ and $28.7-32.7$, respectively) in this study are within those so far reported in the literature (approximately $3-31^{\circ} \mathrm{C}$ and $14-40$ for presence of cells; 12 $31^{\circ} \mathrm{C}$ and $14-40$ for red tides) (Tomas and Smayda 2008, Kim et al. 2010, Richlen et al. 2010, Fatemi et al. 2012, Park et al. 2013a, Mohammad-Noor et al. 2014). The ranges of $\mathrm{NO}_{3}$ and $\mathrm{PO}_{4}$ concentrations at which vegetative cells of C. polykrikoides (0-19 and 0-1.7 $\mu \mathrm{M}$, respectively) or its red tide patches were observed (0.2-4.8 and 0-0.3 $\mu \mathrm{M}$, respectively) are also within the range so far reported in the literature (0-53.7 and 0.1-15.5 $\mu \mathrm{M}$ for cells and red tides) (Tomas and Smayda 2008, Fatemi et al. 2012, Park et al. 2013a). Therefore, C. polykrikoides cells are likely to be present and this species will continuously form red tides in the South Sea of Korea in the future, even when WT increases because of global warming, salinity increases because of long-term drought, and / or nutrient concentrations decrease because of establishment of more sewage treatment systems in Korea. Increases in surface WT (thermoclines shift deeper) and / or salinity (less rainfall) and / or decrease in nutrient concentrations in the future may give C. polykrikoides an advantage over competing species that have lower swimming speeds and high growth rates, as described above.

The results of this study show that the combination of physical, chemical, and biological parameters affects the outbreak, persistence, and decline of C. polykrikoides red tides offshore. Thus, to understand the dynamics of C. polykrikoides red tides and process mechanisms, the investigation of temporal variations in 3-D distributions 
of these parameters is needed. The results of this study provide a basis on establishing conceptual models for predicting the outbreak, persistence, and decline of $C$. polykrikoides red tides.

\section{Insights on the processes of Cochlodinium polykrikoides red tides in the South Sea of Korea}

Based on the results of this study and the literature, insights on the processes of C. polykrikoides can be provided by the following steps: 1) C. polykrikoides can grow exclusively autotrophically and mixotrophically using diverse N sources (Jeong et al. 2004, Kudela et al. 2008, Gobler et al. 2012). In particular, it can rapidly grow at relatively low $\mathrm{NO}_{3}$ concentrations $\left(\mathrm{K}_{1 / 2}\right.$ of $\mathrm{NO}_{3}$ uptake $=$ ca. $\left.2-3 \mu \mathrm{M} \mathrm{NO}_{3}\right)$ (Kim et al. 2001) and thus theoretically can form red tide patches in nearshore waters; 2) however, due to its relatively low maximum growth rate, competitors such as red tide diatoms, small flagellates, and other dinoflagellates usually outcompete $C$. polykrikoides under conditions favorable for all phototrophic organisms. In this competition, relative growth rates between $C$. polykrikoides and competing red tide species at a given condition are likely to be more important than absolute growth rates; 3) Thus, C. polykrikoides can form red tide patches or maintain these patches when the abundance of competitors is low. Theoretically, C. polykrikoides can reach $50 \mathrm{~m}$ depth (Jeong et al. 2015). In this study, the depths favorable for C. polykrikoides are $>20 \mathrm{~m}$. High solar insolation during summer can deepen thermocline, but intrusion of deep cold waters can lift thermocline depths as shown in this study. This condition may be favorable for competing dinoflagellates or flagellates whose reachable depths are shallower and whose growth rates are greater than $C$. polykrikoides. Thus, the retreat period of intruded deep cold waters is likely to give a condition favorable for $C$. polykrikoides; 4) C. polykrikoides is known to kill competitors using allelopathical chemicals (Yamasaki et al. 2007, Tang and Gobler 2010). Thus, C. polykrikoides can maintain its populations by killing competitors if its abundance is very high. High abundance of diatoms, on the other hand, inhibits the growth and migration of $C$. polykrikoides. Thus, when nutrients are supplied to nearshore waters because of freshwater input, upwelling, and / or mixing, diatoms, flagellates, and other fast growing dinoflagellates are likely to outgrow C. polykrikoides and reduce its abundance in red tide patches, which are transported from offshore waters (Fig. 10). In some nearshore waters of the South Sea of Korea, C. polykrikoides red tide patches have often drastically reduced following heavy rains and dominant species changed to diatoms and other dinoflagellates (Lim et al. 2007b, 2008, 2009). Thus, the supply of high nutrients to nearshore waters may be critical to the persistence of $C$. polykrikoides red tide patches in nearshore waters where aquaculture cages are highly concentrated (Fig. 10). The prolonged drought period in 2013 was likely to cause C. polykrikoides red tide patches to remain in nearshore waters of the South Sea of Korea for $>1$ month and cause large mortality of fish in cages at sea and aquaculture tanks on land. During that year, approximately 28 million fish in aquaculture cages and tanks in the South and East Sea of Korea were killed by $C$. polykrikoides red tides (NFRDI 2014).

Large red tide patches formed offshore are often transported to nearshore waters and gradually accumulated there. Dense C. polykrikoides red tide patches with abundances $>10,000$ cells $\mathrm{mL}^{-1}$ were reported at piers located in some nearshore waters of the South Sea (personal observation). Even though the abundance of C. polykrikoides in offshore red tide patches is several hundred or thousand cells $\mathrm{mL}^{-1}$, the abundance of $C$. polykrikoides in nearshore waters can increase by accumulation. If dense $C$. polykrikoides red tide patches in nearshore waters enter aquaculture cages at sea and aquaculture tanks on land, fish are usually killed in a day. On Sep 8, 2014, 0.8 million fish in aquaculture tanks in Namhae were killed by dense C. polykrikoides red tide patches that suddenly appeared. Thus, to reduce large scale mortality of fish in aquaculture cages and tanks because of dense C. polykrikoides red tide patches, the distribution of C. polykrikoides red tides and the related physical, chemical, and biological parameters should be investigated in advance.

The temperature for the optimal growth of C. polykrikoides is approximately $25^{\circ} \mathrm{C}$ (Kudela et al. 2008). Many C. polykrikoides red tide patches in the South Sea of Korea have been found in waters where the temperature is around $25^{\circ} \mathrm{C}$ (NFRDI data; http://www.nifs.go.kr/ portal/redtideInfo). If C. polykrikoides exists alone, it may grow fast and form red tide patches at this temperature. However, the optimal temperature of several competing red-tide species is close to this temperature, as mentioned above. Furthermore, C. polykrikoides cells are likely to experience WTs $<20^{\circ} \mathrm{C}$ whenever it descends to deep cold waters. Strong thermoclines in the South Sea of Korea are formed at depths $>20 \mathrm{~m}$ when surface WTs are $25^{\circ} \mathrm{C}$ unless cold water intrusion occurs. Therefore, $25^{\circ} \mathrm{C}$ in the surface waters may be a signal of the presence of deep strong thermocline that favors C. polykrikoides over its competitors. 


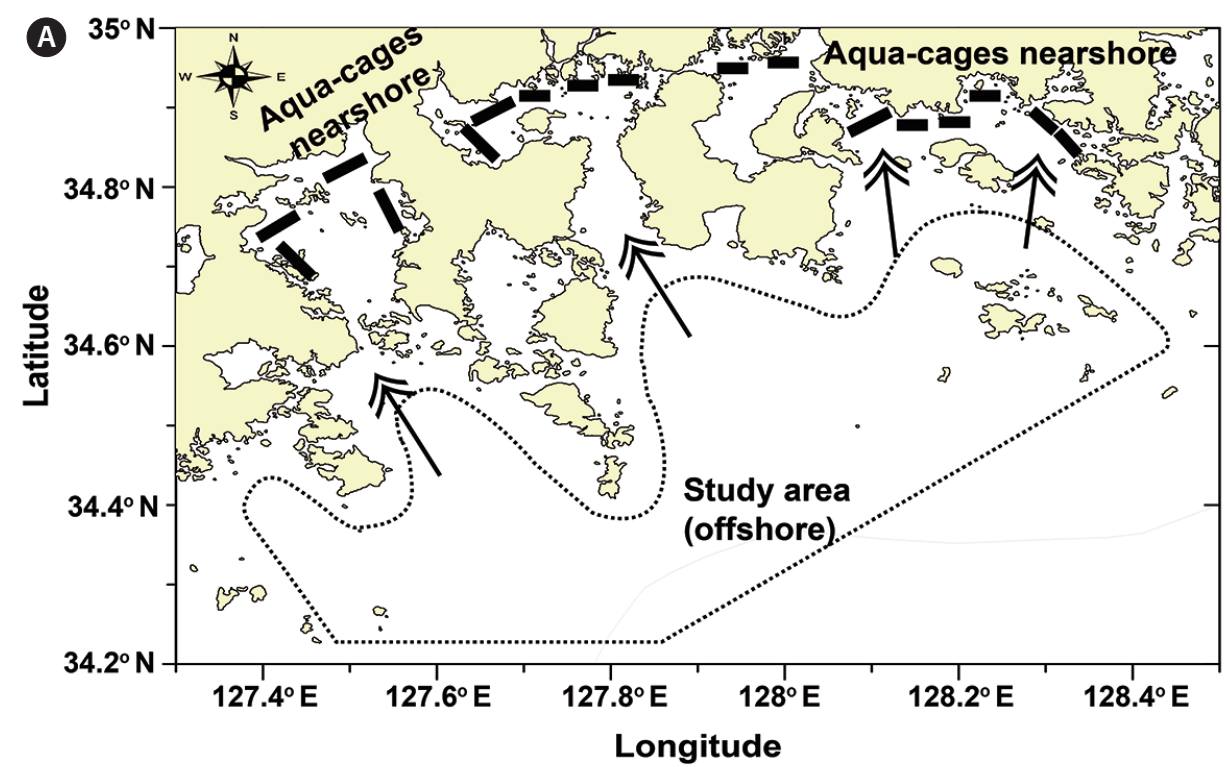

B Nearshore

Offshore

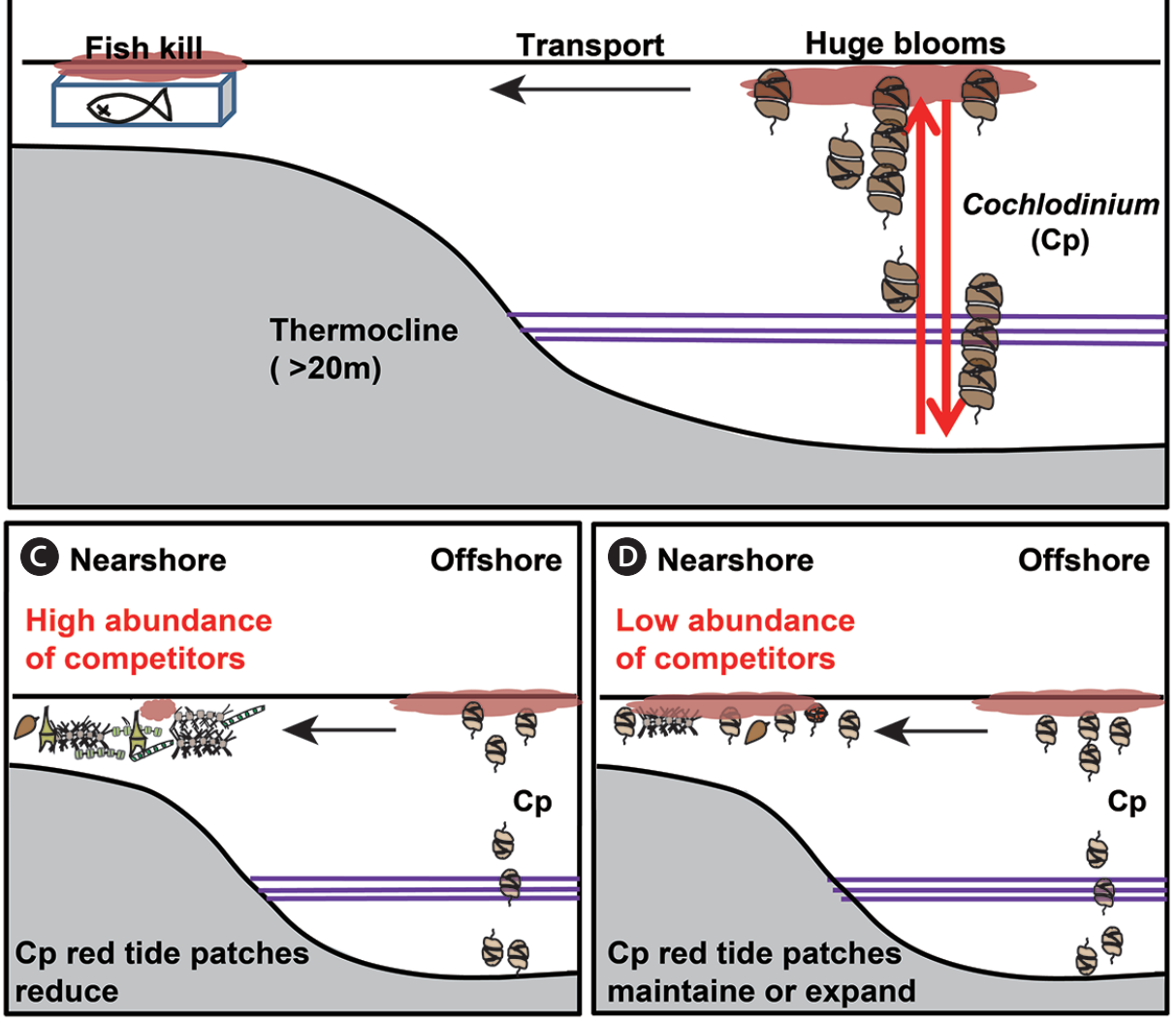

Fig. 10. Diagram showing formation, transport, and persistence of Cochlodinium polykrikoides $(\mathrm{Cp})$ red tide patches in the South Sea of Korea. (A) C. polykrikoides red tide patches offshore are transported to nearshore where aqua-cages are concentrated. The locations (black rods) where aqua-cages nearshore of the South Sea of Korea are established were obtained from images from Google Earth (http://earth.google.com). (B) C. polykrikoides forms its red tide patches offshore by vertical migration when the thermocline depths are $>20 \mathrm{~m}$. (C) C. polykrikoides red tide patches nearshore reduce when the abundances of competitors (i.e., fast growing diatoms, flagellates, and other dinoflagellates) are high. (D) $C$. polykrikoides red tide patches nearshore maintain or expand when the abundances of competitors are low. See texts for details. 


\section{ACKNOWLEDGEMENTS}

We thank Tae Young Jang, Keon Kang Jang, Hak Bin Lee, Sang Beom Lee, Sang Pil Han, Seong Uk Kim, Young Seok Rho, Cheol Kang, Choong Hyeon Choi, and Yeong Du Yoo for technical support. This research was supported by the National Research Foundation (NRF) funded by the Ministry of Science, ICT \& Future Planning (NRF2015M1A5A1041806) and Pilot project for predicting the outbreak of Cochlodinium polykrokoides red tides funded by MSIP (NRF-2014M4A1H5009428) and the useful dinoflagellate program of Korea Institute of Marine Science and Technology Promotion (KIMST) funded by the Ministry of Oceans and Fisheries (MOF) and Management of marine organisms causing ecological disturbance and harmful effect Program of KIMST and award to HJJ.

\section{REFERENCES}

Al-Azri, A. R., Al-Hashimi, K. A., Al-Habsi, H., Al-Azri, N. \& AlKhusaibi, S. 2015. Abundance of harmful algal blooms in the coastal waters of Oman: 2006-2011. Aquat. Ecosyst. Health Manag. 18:269-281.

Al-Azri, A. R., Piontkovski, S. A., Al-Hashimi, K. A., Goes, J. I., Gomes, H. R. \& Glibert, P. M. 2013. Mesoscale and nutrient conditions associated with the massive 2008 Cochlodinium polykrikoides bloom in the Sea of Oman/ Arabian Gulf. Estuar. Coast. 37:325-338.

Al-Hashmi, K. A., Smith, S. L., Claereboudt, M., Piontkovski, S. A. \& Al-Azri, A. 2015. Dynamics of potentially harmful phytoplankton in a semi-enclosed bay in the Sea of Oman. Bull. Mar. Sci. 91:141-166.

Alonso-Rodríguez, R. \& Ochoa, J. L. 2004. Hydrology of winter-spring "red-tides" in Bahía de Mazatlán, Sinaloa, México. Harmful Algae 3:163-171.

Anderson, D. M. 1995. ECOHAB: the ecology and oceanography of harmful algal blooms: a national research agenda. Woods Hole Oceanographic Institute, Woods Hole, MA, $66 \mathrm{pp}$.

Anderson, D. M., Alpermann, T. J., Cembella, A. D., Collos, Y., Masseret, E. \& Montresor, M. 2012. The globally distributed genus Alexandrium: multifaceted roles in marine ecosystems and impacts on human health. Harmful Algae 14:10-35.

Anderson, D. M., Glibert, P. M. \& Burkholder, J. M. 2002. Harmful algal blooms and eutrophication: nutrient sources, composition, and consequences. Estuaries 25:704-726

Anton, A., Teoh, P. L., Mohd-Shaleh, S. R. \& Mohammad-
Noor, N. 2008. First occurrence of Cochlodinium blooms in Sabah, Malaysia. Harmful Algae 7:331-336.

Azanza, R. V., David, L. T., Borja, R. T., Baula, I. U. \& Fukuyo, Y. 2008. An extensive Cochlodinium bloom along the western coast of Palawan, Philippines. Harmful Algae 7:324-330.

Baek, S. H., Shimode, S., Han, M. -S. \& Kikuchi, T. $2008 a$. Growth of dinoflagellates, Ceratium furca and Ceratium fusus in Sagami Bay, Japan: the role of nutrients. Harmful Algae 7:729-739.

Baek, S. H., Shimode, S. \& Kikuchi, T. 2008b. Growth of dinoflagellates, Ceratium furca and Ceratium fusus in Sagami Bay, Japan: the role of temperature, light intensity and photoperiod. Harmful Algae 7:163-173.

Baek, S. H., Shimode, S., Shin, K., Han, M. -S. \& Kikichi, T. 2009. Growth of dinoflagellates, Ceratium furca and Ceratium fusus in Sagami Bay, Japan: the role of vertical migration and cell division. Harmful Algae 8:843-856.

Eaton, A. D., Clesceri, L. S., Greenberg, A. E. \& Franson, M. A. H. 1995. Standard methods for the examination of water and wastewater. 19th ed. American Public Health Association (APHA), Washington, DC, 43 pp.

Eppley, R. W. \& Harrison, W. G. 1975. Physiological ecology of Gonyaulax polyedrum, a red tide water dinoflagellate of southern California. In Locicero, V. R. (Ed.) Prec. 1st Int. Conf. Toxic Dinoflagellate Blooms, Massachusetts Science and Technology Foundation, Wakefield, MA, pp. 11-22.

Fatemi, S. M. R., Nabavi, S. M. B., Vosoghi, G., Fallahi, M. \& Mohammadi, M. 2012. The relation between environmental parameters of Hormuzgan coastline in Persian Gulf and occurrence of the first harmful algal bloom of Cochlodinium polykrikoides (Gymnodiniaceae). Iran. J. Fish. Sci. 11:475-489.

Franks, P. J. S. 1997a. Models of harmful algal blooms. Limnol. Oceanogr. 42:1273-1282.

Franks, P. J. S. 1997b. Spatial patterns in dense algal blooms. Limnol. Oceanogr. 42:1297-1305.

Franks, P. J. S. \& Anderson, D. M. 1992. Alongshore transport of a toxic phytoplankton bloom in a buoyancy current: Alexandrium tamarense in the Gulf of Maine. Mar. Biol. 112:153-164

Fu, F. X., Tatters, A. O. \& Hutchins, D. A. 2012. Global change and the future of harmful algal blooms in the ocean. Mar. Ecol. Prog. Ser. 470:207-233.

Fukuyo, Y., Imai, I., Kodama, M. \& Tamai, K. 2002. Red tides and other harmful algal blooms in Japan. In Tayler, F. J. R. \& Trainer, V. L. (Eds.) Harmful Algal Blooms in the PICES Region of the North Pacific. PICES Sci. Rep. No. 23. North Pacific Marine Science Organization (PICES) In- 
stitute of Ocean Sciences, Sidney, BC, pp. 7-20.

Gárate-Lizárraga, I., López-Cortes, D. J., Bustillo-Guzmán, J. J. \& Hemández-Sandoval, F. 2004. Blooms of Cochlodinium polykrikoides (Gymnodiniaceae) in the Gulf of California, Mexico. Rev. Biol. Trop. 52(Suppl. 1):51-58.

Glibert, P. M., Anderson, D. M., Gentein, P., Granéli, E. \& Sellner, K. G. 2005. The global, complex phenomena of harmful algal blooms. Oceanography 18:136-147.

Gobler, C. J., Berry, D. L., Anderson, O. R., Burson, A., Koch, F., Rodgers, B. S., Moore, L. K., Goleski, J. A., Allam, B., Bowser, P., Tang, Y. \& Nuzzi, R. 2008. Characterization, dynamics, and ecological impacts of harmful Cochlodinium polykrikoides blooms on eastern Long Island, NY, USA. Harmful Algae 7:293-307.

Gobler, C. J., Burson, A., Koch, F., Tang, Y. \& Mulholland, M. R. 2012. The role of nitrogenous nutrients in the occurrence of harmful algal blooms caused by Cochlodinium polykrikoides in New York estuaries (USA). Harmful Algae 17:64-74.

Hamzehei, S., Bidokhti, A. A., Mortazavi, M. S. \& Gheiby, A. 2013. Red tide monitoring in the Persian Gulf and Gulf of Oman using MODIS sensor data. Tech. J. Eng. Appl. Sci. 3:1100-1107.

Han, I. -S., Jang, L. -H., Suh, Y. -S. \& Seong, K. -T. 2008. Relationship between temperature distributions and outbreaks of harmful algal blooms in Korean waters. J. Fish. Sci. Technol. 11:50-60.

Holmes, R. W., Williams, P. M. \& Eppley, R. W. 1967. Red water in La Jolla Bay, 1964-1966. Limnol. Oceanogr. 12:503512.

Horner, R. A., Garrison, D. L. \& Plumley, F. G. 1997. Harmful algal blooms and red tide problems on the U.S. west coast. Limnol. Oceanogr. 42:1076-1088.

Hu, Z., Duan, S., Xu, N. \& Mulholland, M. R. 2014. Growth and nitrogen uptake kinetics in cultured Prorocentrum donghaiense. PLoS One 9:e94030.

Imai, I., Yamaguchi, M. \& Hori, Y. 2006. Eutrophication and occurrences of harmful algal blooms in the Seto Inland Sea, Japan. Plankton Benthos Res. 1:71-84.

Iwataki, M., Kawami, H., Mizushima, K., Mikulski, C. M., Doucette, G. J., Relox, J. R. Jr., Anton, A., Fukuyo, Y. \& Matsuoka, K. 2008. Phylogenetic relationships in the harmful dinoflagellate Cochlodinium polykrikoides (Gymnodiniales, Dinophyceae) inferred from LSU rDNA sequences. Harmful Algae 7:271-277.

Jeong, H. J., Kim, H. R., Kim, K. I., Kim, K. Y., Park, K. H., Kim, S. T., Yoo, Y. D., Song, J. Y., Kim, J. S., Seong, K. A., Yih, W. H., Pae, S. J., Lee, C. H., Huh, M. D. \& Lee, S. H. 2002. $\mathrm{NaOCl}$ produced by electrolysis of natural seawater as a potential method to control marine red-tide dinoflagel- late. Phycologia 41:643-656.

Jeong, H. J., Kim, J. S., Yoo, Y. D., Kim, S. T., Song, J. Y., Kim, T. H., Seong, K. A., Kang, N. S., Kim, M. S., Kim, J. H., Kim, S., Ryu, J., Lee, H. M. \& Yih, W. H. 2008. Control of the harmful alga Cochlodinium polykrikoides by the naked ciliate Strombidinopsis jeokjo in mesocosm enclosures. Harmful Algae 7:368-377.

Jeong, H. J., Lim, A. S., Franks, P. J. S., Lee, K. H., Kim, J. H., Kang, N. S., Lee, M. J., Jang, S. H., Lee, S. Y., Yoon, E. Y., Park, J. Y., Yoo, Y. D., Seong, K. A., Kwon, J. E. \& Jang, T. Y. 2015. A hierarchy of conceptual models of red-tide generation: nutrition, behavior, and biological interactions. Harmful Algae 47:97-115.

Jeong, H. J., Ok, J. H., Lim, A. S., Kwon, J. E., Kim, S. J. \& Lee, S. Y. 2016. Mixotrophy in the phototrophic dinoflagellate Takayama helix (family Kareniaceae): predator of diverse toxic and harmful dinoflagellates. Harmful Algae 60:92-106.

Jeong, H. J., Shim, J. H., Kim, J. S., Park, J. Y., Lee, C. W. \& Lee, Y. 1999. Feeding by the mixotrophic thecate dinoflagellate Fragilidium cf. mexicanum on red-tide and toxic dinoflagellate. Mar. Ecol. Prog. Ser. 176:263-277.

Jeong, H. J., Yoo, Y. D., Kim, J. S., Kim, T. H., Kim, J. H., Kang, N. S. \& Yih, W. 2004. Mixotrophy in the phototrophic harmful alga Cochlodinium polykrikoides (Dinophycean): prey species, the effects of prey concentration and grazing impact. J. Eukaryot. Microbiol. 51:563-569.

Jeong, H. J., Yoo, Y. D., Kim, J. S., Seong, K. A., Kang, N. S. \& Kim, T. H. 2010. Growth, feeding, and ecological roles of the mixotrophic and heterotrophic dinoflagellates in marine planktonic food webs. Ocean Sci. J. 45:65-91.

Jeong, H. J., Yoo, Y. D., Lee, K. H., Kim, T. H., Seong, K. A., Kang, N. S., Lee, S. Y., Kim, J. S., Kim, S. \&Yih, W. H. 2013. Red tides in Masan Bay, Korea in 2004-2005: I. Daily variations in the abundance of red-tide organisms and environmental factors. Harmful Algae 30(Suppl. 1):S75-S88.

Kaneda, A., Takeoka, H., Nagaura, E. \& Koizumi, Y. 2002. Periodic intrusion of cold water from the Pacific Ocean into the bottom layer of the Bungo Channel in Japan. J. Oceanogr. 58:547-556.

Kim, D. -I., Matsuyama, Y., Nagasoe, S., Yamaguchi, M., Yoon, Y. -H., Oshima, Y., Imada, N. \& Honjo, T. 2004. Effects of temperature, salinity and irradiance on the growth of the harmful red tide dinoflagellate Cochlodinidum polykrikoides Margalef (Dinophyceae). J. Plankton Res. 26:61-66.

Kim, H. C., Lee, C. K., Lee, S. G., Kim, H. G. \& Park, C. K. 2001. Physico-chemical factors on the growth of Cochlodinium polykrikoides and nutrient utilization. J. Korean Fish. Soc. 34:445-456. 
Kim, Y. S., Jeong, C. S., Seong, G. T., Han, I. S. \& Lee, Y. S. 2010. Diurnal vertical migration of Cochlodinium polykrikoides during the red tide in Korean coastal sea waters. J. Environ. Biol. 31:687-693.

Kudela, R. M. \& Gobler, C. J. 2012. Harmful dinoflagellate blooms caused by Cochlodinium sp.: global expansion and ecological strategies facilitating bloom formation. Harmful Algae 14:71-86.

Kudela, R. M., Ryan, J. P., Blakely, M. D., Lane, J. Q. \& Peterson, T. D. 2008. Linking the physiology and ecology of Cochlodinium to better understand harmful algal bloom events: a comparative approach. Harmful Algae 7:278-292.

Lee, C. -K., Park, T. -G., Park, Y. -T. \& Lim, W. -A. 2013. Monitoring and trends in harmful algal blooms and red tides in Korean coastal waters, with emphasis on Cochlodinium polykrikoides. Harmful Algae 30(Suppl. 1):S3-S14.

Lee, C., Park, Y., Park, T. \& Suh, Y. 2014a. Economic losses to the aquaculture industry by harmful algal blooms in Korea since 2001. PICES Sci. Rep. 47:35-40.

Lee, K. H., Jeong, H. J., Kwon, J. E., Kang, H. C., Kim, J. H., Jang, S. H., Park, J. Y., Yoon, E. Y. \& Kim, J. S. 2016. Mixotrophic ability of the phototrophic dinoflagellates Alexandrium andersonii, A. affine, and A. fraterculus. Harmful Algae 59:67-81.

Lee, K. H., Jeong, H. J., Yoon, E. Y., Jang, S. H., Kim, H. S. \& Yih, W. 2014b. Feeding by common heterotrophic dinoflagellates and a ciliate on the red-tide ciliate Mesodinium rubrum. Algae 29:153-163.

Lee, M., Kim, B., Kwon, Y. \& Kim, J. 2009. Characteristics of the marine environment and algal blooms in Gamak Bay. Fish. Sci. 75:401-411.

Lim, A. S., Jeong, H. J., Jang, T. Y., Jang, S. H. \& Franks, P. J. S. 2014. Inhibition of growth rate and swimming speed of the harmful dinoflagellate Cochlodinium polykrikoides by diatoms: implications for red tide formation. Harmful Algae 37:53-61.

Lim, A. S., Jeong, H. J., Jang, T. Y., Kang, N. S., Jang, S. H. \& Lee, M. J. 2015. Differential effects of typhoons on ichthyotoxic Cochlodinium polykrikoides red tides in the South Sea of Korea during 2012-2014. Harmful Algae 45:26-32.

Lim, A. S., Jeong, H. J., Kim, J. H. \& Lee, S. Y. 2017. Control of ichthyotoxic Cochlodinium polykrikoides using the mixotrophic dinoflagellate Alexandrium pohangense: a potential effective sustainable method. Harmful Algae 63:109-118.

Lim, P. -T., Leaw, C. -P., Kaga, S., Sekiguchi, K. \& Ogata, T. 2007a. Growth responses of five non toxic Alexandrium species (dinophyceae) to temperature and salinity. Mar. Res. Indonesia 32:189-195.
Lim, W. -A., Lee, Y. -S. \& Lee, S. -G. 2008. Characteristics of environmental factors related to outbreak and decline of Cochlodinium polykrikoides bloom in the southeast coastal waters of Korea, 2007. J. Korean Soc. Oceanogr. 13:325-332 (in Korean with English abstract).

Lim, W. -A., Lee, Y. -S., Lee, S. -G. \& Lee, J. -Y. 2007b. Distribution and community structure of phytoplankton in the southeast coastal waters during Summer 2006. J. Korean Soc. Oceanogr. 12:370-379 (in Korean with English abstract).

Lim, W. -A., Lee, Y. -S. \& Park, J. -G. 2009. Characteristics of Cochlodinium polykrikoides bloom in southeast coastal waters of Korea, 2008. J. Korean Soc. Oceanogr. 14:155162 (in Korean with English abstract).

Menden-Deuer, S. \& Montalbano, A. L. 2015. Bloom formation potential in the harmful dinoflagellate Akashiwo sanguinea: clues from movement behaviors and growth characteristics. Harmful Algae 47:75-85.

Mohammad-Noor, N., Weliyadi, E., Aung, T., Adam, A. \& Hanan, D. S. M. 2014. Effects of meteorological conditions on the occurrence of Cochlodinium polykrikoides and Pyrodinium bahamense var. compressum in coastal waters of Kota Kinabalu, Sabah, Malaysia. Sains Malaysiana 43:21-29.

Morse, R. E., Mulholland, M. R., Hunley, W. S., Fentress, S., Wiggins, M. \& Blanco-Garcia, J. L. 2013. Controls on the initiation and development of blooms of the dinoflagellate Cochlodinium polykrikoides Margalef in lower Chesapeake Bay and its tributaries. Harmful Algae 28:71-82.

Morse, R. E., Shen, J., Blanco-Garcia, J. L., Hunley, W. S., Fentress, S., Wiggins, M. \& Mulholland, M. R. 2011. Environmental and physical controls on the formation and transport of blooms of the dinoflagellate Cochlodinium polykrikoides Margalef in the lower Chesapeake Bay and its tributaries. Estuar. Coast. 34:1006-1025.

Mulholland, M. R., Morse, R. E., Boneillo, G. E., Bernhardt, P. W., Filippino, K. C., Procise, L. A., Blanco-Garcia, J. L., Marshall, H. G., Egerton, T. A., Hunley, W. S., Moore, K. A., Berry, D. L. \& Gobler, C. J. 2009. Understanding causes and impacts of the dinoflagellate, Cochlodinium polykrikoides, blooms in the Chesapeake Bay. Estuar. Coast. 32:734-747.

National Fisheries Research and Development Institute (NFRDI). 2014. Harmful algal blooms in Korean nearshore waters in 2013. Research report of National Fisheries Research and Development Institute. National Fisheries Research and Development Institute, Incheon, 173 pp. (in Korean).

Nuzzi, R. 2004. Cochlodinium polykrikoides in the Peconic Estuary. Harmful Algae News 27:10-11. 
Onitsuka, G., Miyahara, K., Hirose, N., Watanabe, S., Semura, H., Hori, R., Nishkawa, T., Miyaji, K. \& Yamaguchi, M. 2010. Large-scale transport of Cochlodinium polykrikoides blooms by the Tsushima Warm Current in the southwest Sea of Japan. Harmful Algae 9:390-397.

Park, B. S., Wang, P., Kim, J. H., Kim, J. -H., Gobler, C. J. \& Han, M. -S. 2014. Resolving the intra-specific succession within Cochlodinium polykrikoides populations in southern Korean coastal waters via use of quantitative PCR assays. Harmful Algae 37:133-141.

Park, J., Jeong, H. J., Yoo, Y. D. \& Yoon, E. Y. 2013a. Mixotrophic dinoflagellate red tides in Korean waters: distribution and ecophysiology. Harmful Algae 30(Suppl. 1):S28-S40.

Park, T. G., Lim, W. A., Park, Y. T., Lee, C. K. \& Jeong, H. J. $2013 b$. Economic impact, management and mitigation of red tides in Korea. Harmful Algae 30(Suppl. 1):S131-S143.

Qasim, S. Z., Bhattathiri, P. M. A. \& Devassy, V. P. 1973. Growth kinetics and nutrient requirements of two tropical marine phytoplankters. Mar. Biol. 21:299-304.

Richlen, M. L., Morton, S. L., Jamali, E. A., Rajan, A. \& Anderson, D. M. 2010. The catastrophic 2008-2009 red tides in the Arabian Gulf region, with observations on the identification and phylogeny of the fish-killing dinoflagellate Cochlodinium polykrikoides. Harmful Algae 9:163-172.

Seong, K. A., Jeong, H. J., Kim, S., Kim, G. H. \& Kang, J. H. 2006. Bacterivory by co-occurring red-tide algae, heterotrophic nanoflagellates, and ciliates. Mar. Ecol. Prog. Ser. 322:85-97.

Smayda, T. J. 1990. Novel and nuisance phytoplankton blooms in the sea: evidence for a global epidemic. In Granéli, E., Sundström, B., Edler, L. \& Anderson, D. M. (Eds.) Toxic Marine Phytoplankton. Elsevier Publishers B.V., Amsterdam, pp. 29-40.

Smayda, T. J. 2010. Adaptations and selection of harmful and other dinoflagellate species in upwelling systems. 2. Motility and migratory behaviour. Prog. Oceanogr. 85:71-91.

Sordo, I., Barton, E. D., Cotos, J. M. \& Pazos, Y. 2001. An inshore poleward current in the NW of the Iberian Peninsula detected from satellite images, and its relation with G. catenatum and D. acuminata blooms in the Galician Rias. Estuar. Coast. Shelf Sci. 53:787-799.

Tang, Y. Z. \& Gobler, C. J. 2010. Allelopathic effects of Cochlodinium polykrikoides isolates and blooms from the estuaries of Long Island, New York, on co-occurring phytoplankton. Mar. Ecol. Prog. Ser. 406:19-31.
Tomas, C. R. \& Smayda, T. J. 2008. Red tide blooms of Cochlodinium polykrikoides in a coastal cove. Harmful Algae 7:308-317.

Vargas-Montero, M., Freer, E., Jiménez-Montealegre, R. \& Guzmán, J. C. 2006. Occurrence and predominance of the fish killer Cochlodinium polykrikoides on the Pacific coast of Costa Rica. Afr. J. Mar. Sci. 28:215-217.

Welch, P. S. 1948. Limnological methods. Blaikston Co., Philadelphia, PA, 381 pp.

Whyte, J. N. C., Haigh, N., Ginther, N. G. \& Keddy, L. J. 2001. First record of blooms of Cochlodinium sp. (Gymnodiniales, Dinophyceae) causing mortality to aquacultured salmon on the west coast of Canada. Phycologia 40:298304.

Xu, N., Duan, S., Li, A., Zhang, C., Cai, Z. \& Hu, Z. 2010. Effects of temperature, salinity and irradiance on the growth of the harmful dinoflagellate Prorocentrum donghaiense Lu. Harmful Algae 9:13-17.

Yamasaki, Y., Nagasoe, S., Matsubara, T., Shikata, T., Shimasaki, Y., Oshima, Y. \& Honjo, T. 2007. Growth inhibition and formation of morphologically abnormal cells of Akashiwo sanguinea (Hirasaka) G. Hansen et Moestrup by cell contact with Cochlodinium polykrikoides Margalef. Mar. Biol. 152:157-163.

Yamatogi, T., Sakaguchi, M., Iwataki, M. \& Matsuoka, K. 2006. Effects of temperature and salinity on the growth of four harmful red tide flagellates occurring in Isahaya Bay in Ariake Sound, Japan. Nippon Suisan Gakkaishi 72:160168.

Yamatogi, T., Sakaguti, M., Takagi, N., Iwataki, M. \& Matsuoka, K. 2005. Effects of temperature, salinity and light intensity on the growth of a harmful dinoflagellate $\mathrm{Co}$ chlodinium polykrikoides Margalef occurring in coastal waters of west Kyushu, Japan. Bull. Plankton Soc. Jpn. 52:4-10.

Yan, T., Zhou, M. -J. \& Zou, J. -Z. 2002. A national report on harmful algal blooms in China. In Tayler, F. J. R. \& Trainer, V. L. (Eds.) Harmful Algal Blooms in the PICES Region of the North Pacific. PICES Sci. Rep. No. 23. North Pacific Marine Science Organization (PICES) Institute of Ocean Sciences, Sidney, BC, pp. 21-38.

Yoon, D. -Y. \& Choi, H. -W. 2012. Development of algorithms for extracting thermocline parameters in the South Sea of Korea. Ocean Polar Res. 34:265-273 (in Korean with English abstract, tables, and figures). 
Appendix 1. List of phototrophic plankton and their maximum abundance (MA; cells $\mathrm{mL}^{-1}$ ) in the South Sea, Korea, from May to Nov 2014

\begin{tabular}{|c|c|c|c|c|c|c|c|c|}
\hline Taxon & May & Jun & Jul & Aug & Sep & Oct & Nov & MA \\
\hline \multicolumn{9}{|l|}{ Diatoms } \\
\hline Achnanthes sp. & & & & + & + & & & 6 \\
\hline Actinoptychus undulatus & + & + & + & + & + & + & + & 48 \\
\hline Amphiprora alata & + & + & + & + & + & + & + & 3 \\
\hline Amphiprora gigantea & + & & + & & & & + & 9 \\
\hline Amphiprora sp. & + & + & & & & & & 1 \\
\hline Asterionella formosa & & & + & & & & & 4 \\
\hline Asterionella glacialis & + & + & + & + & + & + & + & 67 \\
\hline Asterionella kariana & + & + & + & & & & & 7 \\
\hline Asterionella sp. & + & & & & & & & 2 \\
\hline Asteromphalus sp. & + & & + & + & + & + & + & 10 \\
\hline Attheya septentrionalis & & & + & & & & + & 2 \\
\hline Aulacoseira granulata. & + & & & & & & & 1 \\
\hline Aulacoseira spp. & + & + & & + & + & & & 11 \\
\hline Bacillaria paxillifera & + & + & + & + & + & + & + & 37 \\
\hline Bacteriastrum hyalina & + & + & & & & & & 6 \\
\hline Bacteriastrum sp. & + & + & + & + & + & + & + & 29 \\
\hline Biddulphia logicruris & + & + & + & + & + & + & + & 14 \\
\hline Biddulphia sinensis & + & + & + & + & + & + & + & 4 \\
\hline Biddulphia sp. & & & + & & & & & 1 \\
\hline Cerataulina sp. & + & + & + & + & + & + & & 68 \\
\hline Chaetoceros affinis & + & + & + & + & + & + & + & 396 \\
\hline Chaetoceros borealis & + & + & + & + & + & + & + & 154 \\
\hline Chaetoceros coarctatus & + & & + & + & + & + & + & 23 \\
\hline Chaetoceros compressus & + & + & + & + & + & + & + & 325 \\
\hline Chaetoceros constrictus & & & + & & + & & + & 90 \\
\hline Chaetoceros crinictus & & + & + & & + & & & 157 \\
\hline Chaetoceros curvisetus & + & + & + & + & + & + & + & 1,274 \\
\hline Chaetoceros danicus & + & + & + & + & + & + & + & 25 \\
\hline Chaetoceros debilis & & & + & & & & & 9 \\
\hline Chaetoceros decipiens & + & + & + & + & + & + & + & 150 \\
\hline Chaetoceros didymus & + & + & + & + & + & + & + & 32 \\
\hline Chaetoceros distansa & & & + & + & + & & + & 35 \\
\hline Chaetoceros eibenii & + & + & + & + & + & + & + & 91 \\
\hline Chaetoceros frichei & + & + & + & + & + & & & 7 \\
\hline Chaetoceros lorenzianus & & & & & & + & & 19 \\
\hline Chaetoceros messanenses & & & & & & & + & 3 \\
\hline Chaetoceros siamensis & & + & & & & & & 8 \\
\hline Chaetoceros similis & & + & + & + & + & + & & 7 \\
\hline Chaetoceros socialis & + & + & + & + & + & & + & 428 \\
\hline Chaetoceros spp. & + & + & + & + & + & + & & 74 \\
\hline Chaetoceros subsecundus & + & & + & & & + & + & 10 \\
\hline Chaetoceros teres & + & + & + & + & + & + & + & 27 \\
\hline Chaetoceros vanherchi & & & & & & & + & 1 \\
\hline Corethron spp. & + & + & + & + & + & + & + & 3 \\
\hline Coscinodiscus sp. & + & + & + & + & + & + & + & 46 \\
\hline Coscinodiscus wailesii & + & + & + & + & + & + & & 24 \\
\hline Coscinosira oestrupi & & + & + & & & & & 2 \\
\hline Cyclotella sp. & & & & & + & + & & 45 \\
\hline Cylindrotheca closterium & + & + & + & + & + & + & + & 4 \\
\hline Cylindrotheca fusiformis & + & & & & & & & 1 \\
\hline Cymbella sp. & + & & & & + & & & 1 \\
\hline Dactyliosolen fragilissimus & + & + & + & + & + & + & + & 9 \\
\hline Detonula pumila & + & & + & + & + & & + & 12 \\
\hline Diatoma elongatum & + & & & & & + & + & 8 \\
\hline Diatoma sp. & & + & + & + & + & + & + & 31 \\
\hline Ditylum brightwellii & + & + & + & + & + & + & + & 15 \\
\hline Ditylum sol & & & & & & & + & 5 \\
\hline Eucampia zodiacus & + & + & + & + & + & + & + & 13,005 \\
\hline Fragilaria construens & & & + & & + & + & & 8 \\
\hline Fragilaria spp. & + & + & + & + & + & + & + & 16 \\
\hline Grammatophora marina & + & & + & & & & & 36 \\
\hline
\end{tabular}


Appendix 1. Continued

\begin{tabular}{|c|c|c|c|c|c|c|c|c|}
\hline Taxon & May & Jun & Jul & Aug & Sep & Oct & Nov & MA \\
\hline \multicolumn{9}{|l|}{ Diatoms } \\
\hline Guinardia delicatula & + & + & + & + & + & + & & 150 \\
\hline Guinardia flaccida & + & + & + & + & + & + & + & 44 \\
\hline Guinardia striata & + & + & + & + & + & + & + & 27 \\
\hline Gyrosigma fasciola & & + & & & & & & 1 \\
\hline Hemiaulus hauckii & + & + & + & + & + & + & + & 12 \\
\hline Hemiaulus sinensis & + & & + & + & + & & & 4 \\
\hline Hyalodiscus stelliger & + & & + & & + & & & 2 \\
\hline Lauderia borealis & + & + & + & + & + & + & + & 225 \\
\hline Lauderia glacialis & + & + & & & & + & + & 8 \\
\hline Leptocylindrus danicus & + & + & + & + & + & + & + & 698 \\
\hline Leptocylindrus mediterraneus & + & + & + & + & + & + & + & 405 \\
\hline Licmophora abbreviata & + & + & + & + & + & + & & 5 \\
\hline Melosira sp. & + & & + & + & + & & & 6 \\
\hline Menuinera sp. & + & + & + & + & + & + & & 40 \\
\hline Navicula directa & + & + & + & & + & & + & 2 \\
\hline Navicula distans & + & + & + & + & & & + & 2 \\
\hline Navicula spp. & + & + & + & + & + & + & + & 13 \\
\hline Nitzschia longissima & + & + & + & + & + & + & + & 8 \\
\hline Nitzschia sigma & + & + & + & + & + & + & + & 3 \\
\hline Nitzschia sp. & + & + & + & + & + & + & + & 7 \\
\hline Nitzschioid & + & + & + & + & + & + & + & 7 \\
\hline Paralia sulcata & + & + & + & + & + & + & + & 133 \\
\hline Pinnularia sp. & + & & & + & + & + & & 1 \\
\hline Plagiogramma vanheurckii & & & & & + & & & 5 \\
\hline Planktoniella blanda & + & + & + & + & + & + & + & 4 \\
\hline Pleurosigma angulatum & + & + & + & + & + & + & + & 6 \\
\hline Psedocrinitus sp. & + & + & + & + & + & & & 12 \\
\hline Psedonitzschia pungens & + & + & + & + & + & + & + & 335 \\
\hline Psedonitzschia spp. & + & + & + & + & + & + & + & 749 \\
\hline Psedonizhicia seriata & + & & + & & + & & + & 383 \\
\hline Psedonizschia granii & + & + & + & + & + & + & + & 77 \\
\hline Psedonizschia multiseries & + & + & + & + & + & + & + & 135 \\
\hline Pyrosigma fasciola & & + & + & & & & & 12 \\
\hline Rhabdonema sp. & & & & & + & & + & 2 \\
\hline Rhizosolenia alata & + & + & + & + & + & + & + & 10 \\
\hline Rhizosolenia calcar & + & + & + & + & + & + & + & 15 \\
\hline Rhizosolenia robusta & + & + & + & + & + & + & + & 5 \\
\hline Rhizosolenia setigera & + & + & + & + & + & + & + & 35 \\
\hline Rhizosolenia sp. & & + & & + & & & + & 16 \\
\hline Sigmoid & + & + & + & + & + & + & + & 18 \\
\hline Skeletonema costatum & + & + & + & + & + & + & + & 1,386 \\
\hline Stephanopyxis palmeriana & + & + & + & + & + & + & + & 30 \\
\hline Stephanopyxis turris & & + & & & & + & & 3 \\
\hline Streptothea thamensis & & & + & + & + & + & + & 3 \\
\hline Surirella sp. & + & + & + & & + & + & + & 2 \\
\hline Synedra sp. & + & + & + & + & + & + & + & 6 \\
\hline Thalassionema bacillare & + & + & + & & + & & & 6 \\
\hline Thalassionema frauenfeldii & + & + & + & + & + & + & + & 44 \\
\hline Thalassionema nitzschioides & + & + & + & + & + & + & + & 230 \\
\hline Thalassionema nordenskioeldii & + & & + & & & + & & 4 \\
\hline Thalassiosira decipiens & + & + & + & + & + & + & + & 810 \\
\hline Thalassiosira porosia & + & + & + & + & + & + & + & 9 \\
\hline Thalassiosira rotula & + & + & + & + & + & + & + & 28 \\
\hline Thalassiosira subtilus & + & + & + & + & + & + & + & 123 \\
\hline Thalassiosira spp. & + & + & + & + & + & + & + & 116 \\
\hline Triceratium sp. & + & & & & + & & & 1 \\
\hline Centric diatom & & + & & + & & & & 4 \\
\hline \multicolumn{9}{|l|}{ Phototrophic dinoflagellates } \\
\hline Akashiwo sanguinea & + & + & + & + & + & + & + & 5 \\
\hline Alexandrium sp. & + & + & + & + & + & + & + & 1,276 \\
\hline Amphidinium longum & + & & & + & + & & & 4 \\
\hline
\end{tabular}


Appendix 1. Continued

\begin{tabular}{|c|c|c|c|c|c|c|c|c|}
\hline Taxon & May & Jun & Jul & Aug & Sep & Oct & Nov & MA \\
\hline \multicolumn{9}{|l|}{ Phototrophic dinoflagellates } \\
\hline Amphidinium sphaeocysticola & + & + & + & & + & & + & 5 \\
\hline Amphidinium poecilochrom & + & + & + & & & & & 2 \\
\hline Amphidinium sp. & + & + & + & + & & & & 2 \\
\hline Ceratium furca & + & + & + & + & + & + & + & 400 \\
\hline Ceratium fusus & + & + & + & + & + & + & + & 68 \\
\hline Ceratium kofoidii & + & + & + & + & + & + & + & 9 \\
\hline Ceratium macroceros & & & + & & + & + & & 3 \\
\hline Ceratium pentagonum & + & & & & + & + & & 1 \\
\hline Ceratium tripos & + & + & & + & + & + & + & 6 \\
\hline Cochlodinium polykrikoides & + & + & + & + & + & + & + & 2,989 \\
\hline Cochlodinium sp. & + & & + & & & & & 18 \\
\hline Dinophysis acuminatum & + & + & + & + & + & + & & 7 \\
\hline Dinophysis caudata & & + & + & + & + & + & + & 10 \\
\hline Dinophysis ovum & + & + & + & + & & + & & 4 \\
\hline Dinophysis rotundata & + & + & + & + & + & + & & 2 \\
\hline Dinophysis sp. & + & & + & & + & & & 1 \\
\hline Gonyaulax sp. & + & + & + & + & + & + & + & 40 \\
\hline Gymnodinium spp. & + & + & + & + & + & + & + & 89 \\
\hline Heterocapsa triquetra & + & + & + & + & & & & 4 \\
\hline Heterocapsa rotundata & + & + & + & + & + & + & & 1 \\
\hline Heterocapsa sp. & + & + & + & + & + & & & 393 \\
\hline Karenia mikimotoi & + & + & + & + & + & & & 36 \\
\hline Karlodinium sp. & + & + & + & + & + & & & 354 \\
\hline Nematodinium sp. & + & + & & & & & & 11 \\
\hline Oxytoxum sp. & + & + & + & + & + & + & & 4 \\
\hline Phaopolykrikos hartmannii & + & + & + & + & + & + & & 1 \\
\hline Prorocentrum balticum & + & + & + & & & & & 393 \\
\hline Prorocentrum gracialis & + & + & + & & + & & & 7 \\
\hline Prorocentrum micans & + & & + & & + & & & 1 \\
\hline Prorocentrum minimum & + & + & + & + & + & + & & 8 \\
\hline Prorocentrum triestinum & + & + & + & + & + & + & + & 505 \\
\hline Prorocentrum sp. & + & + & + & + & + & + & & 4 \\
\hline Pyrocystis lunula & & & & & & & + & 1 \\
\hline Pyrophacus sp. & + & + & + & + & & + & + & 1 \\
\hline Scrippsiella trochodea & + & + & + & + & & + & & 51 \\
\hline Scrippsiella sp. & + & + & + & + & + & + & + & 191 \\
\hline Torodinium sp. & + & + & + & + & + & + & + & 9 \\
\hline \multicolumn{9}{|l|}{ Raphidophytes } \\
\hline Chattonella sp. & + & + & + & + & + & + & + & 57 \\
\hline Heterosigma akashiwo & + & + & + & + & & & & 39 \\
\hline \multicolumn{9}{|l|}{ Cryptophytes } \\
\hline Crytomonad A & + & + & + & + & + & + & + & 4,350 \\
\hline Crytomonad B & + & + & + & & + & & & 6 \\
\hline Crytomonad C & + & & & & & & & 1 \\
\hline \multicolumn{9}{|l|}{ Dictyochophytes } \\
\hline Distephanus speculum var. octonarium & + & + & + & + & + & & & 229 \\
\hline Ebria tripartita & + & + & + & + & + & & & 5 \\
\hline Dictyocha fibula & + & + & + & + & & & & 13 \\
\hline \multicolumn{9}{|l|}{ Euglenophytes } \\
\hline Euglenoid & + & + & + & + & + & & + & 11 \\
\hline \multicolumn{9}{|l|}{ Chlorophytes } \\
\hline Actinastrum hantschii & + & & & & & & & 2 \\
\hline \multicolumn{9}{|l|}{ Prasinophytes } \\
\hline Tetraselmis sp. & + & + & + & & & + & & 983 \\
\hline \multicolumn{9}{|l|}{ Mixotrophic ciliates } \\
\hline Mesodinium ruburum & + & + & + & + & + & + & + & 575 \\
\hline
\end{tabular}

